\title{
Geochemistry and zircon U-Pb age of subvolcanic rocks in Dajing deposit, NE China: Geodynamic implications
}

\author{
Wei MeI, ${ }^{1}$ Xinbiao LÜ, ${ }^{1.2 *}$ Zhilong Ai, ${ }^{3}$ RAnKUn TANG, ${ }^{1}$ ZHI LiU $^{1}$ and YAN ZhaO ${ }^{1}$ \\ ${ }^{1}$ Faculty of Earth Resources, China University of Geosciences, Wuhan 430074, China \\ ${ }^{2}$ Geological Survey of China University of Geosciences, Wuhan 430074, China \\ ${ }^{3}$ Development Department, Hubei Geological Survey, Wuhan 430034, China
}

(Received November 6, 2013; Accepted April 19, 2014)

\begin{abstract}
The Dajing deposit is a large-scale vein-type polymetallic Sn deposit in the southern Great Xing'an Range of Northeast China. This study presents new geochronological and geochemical data for subvolcanic rocks associated with the Dajing deposit and discusses the petrogenesis and tectonic setting of these rocks. The subvolcanic rocks associated with the Dajing deposit are felsites, porphyritic andesites, and porphyritic dacites. Laser-ablation inductively coupled plasmamass spectrometry (LA-ICP-MS) U-Pb Zircon dating undertaken during this study indicates that the porphyritic dacite was intruded during the late Permian $(265.9 \pm 5.4 \mathrm{Ma})$, whereas both the felsite and the porphyritic andesite were intruded during the Middle Jurassic (168.4 \pm 5.0 and 175.5 $\pm 5.6 \mathrm{Ma}$, respectively). All of these subvolcanic rocks are of the high$\mathrm{K}$ calc-alkaline series, with high A/CNK $\left(=\left(\mathrm{Al}_{2} \mathrm{O}_{3}\right) /\left(\mathrm{CaO}+\mathrm{Na}_{2} \mathrm{O}+\mathrm{K}_{2} \mathrm{O}\right)\right)$ molecular ratios $(>1)$, and are LREE-enriched relative to the HREEs. The felsite is characterized by relatively high $\mathrm{Rb}, \mathrm{U}, \mathrm{Nd}, \mathrm{Zr}$, and $\mathrm{Hf}$, and relatively low $\mathrm{Eu}, \mathrm{Ba}$, $\mathrm{Sr}$, $\mathrm{P}$, and Ti concentrations, and is geochemically similar to highly fractionated I-type granites. In comparison, the porphyritic andesite is characterized by relatively high $\mathrm{Rb}$ and $\mathrm{K}$ and relatively low $\mathrm{Ba}$ concentrations, and is geochemically similar to unfractionated I-type granites. The porphyritic dacite is enriched in $\mathrm{Rb}, \mathrm{Zr}$, and $\mathrm{Hf}$, is depleted in $\mathrm{Ba}, \mathrm{Sr}, \mathrm{P}$, and $\mathrm{Ti}$, and is geochemically similar to $\mathrm{A}_{2}$-type granites. The regional geological setting and geochemistry of these subvolcanic rocks indicate that both the felsite and porphyritic andesite formed during post-collisional extension within the Xingmeng Orogenic Belt. This extension was a far-field effect of the closure of the Mongol-Okhotsk Ocean and associated lithospheric delamination during the Middle Jurassic. In comparison, the porphyritic dacite was associated with post-collisional slab break-off.
\end{abstract}

Keywords: Dajing deposit, subvolcanic rocks, U-Pb dating, geochemistry

\section{INTRODUCTION}

The southern Great Xing'an Range of NE China is located in the eastern Central Asian Orogenic Belt (Xingmeng Orogenic Belt) and hosts voluminous Mesozoic intrusive and volcanic rocks. Recent research into the petrology and tectonic setting of these rocks indicates that the majority of intrusive and volcanic rocks formed during the Early Cretaceous (Ge et al., 2000; Lin et al., 2004; Wu et al., 2005; Wang, F. et al., 2006; Liu et al., 2005, 2009). However, little research has been undertaken on Jurassic intrusives in this area, meaning that the petrogenesis of the rocks and the tectonic setting in which they formed are poorly understood. This study provides new, precise $\mathrm{U}-\mathrm{Pb}$ ages for Jurassic subvolcanic rocks in the study area to address these shortcomings.

The Dajing deposit is a large-scale vein-type

\footnotetext{
*Corresponding author (e-mail: 1vxb_01@163.com)

Copyright $@ 2014$ by The Geochemical Society of Japan.
}

polymetallic Sn deposit located in the southern Great Xing' an Range. Previous studies on this deposit have generally focused on the geology (Wang et al., 2001), mineralogy (Wang, Y. W. et al., 2002, 2006), petrology (Zhang et al., 2011), and geochronology (Jiang et al., 2012; Liao et al., 2012), although the majority of these studies have only been published in Chinese. Consequently, an updated and more detailed description of subvolcanic rocks associated with the Dajing deposit and the tectonic setting in which this magmatism occurred is still required.

This study provides new $\mathrm{U}-\mathrm{Pb}$ isotopic ages and geochemical data for Jurassic and Permian subvolcanic rocks associated with the Dajing deposit that constrain the petrogenesis and tectonic setting of this magmatism.

\section{Regional GeOlogy}

The Paleozoic history of NE China is dominated by the amalgamation of several micro-continental blocks or terranes (Wu et al., 2011), such as the northwestern 


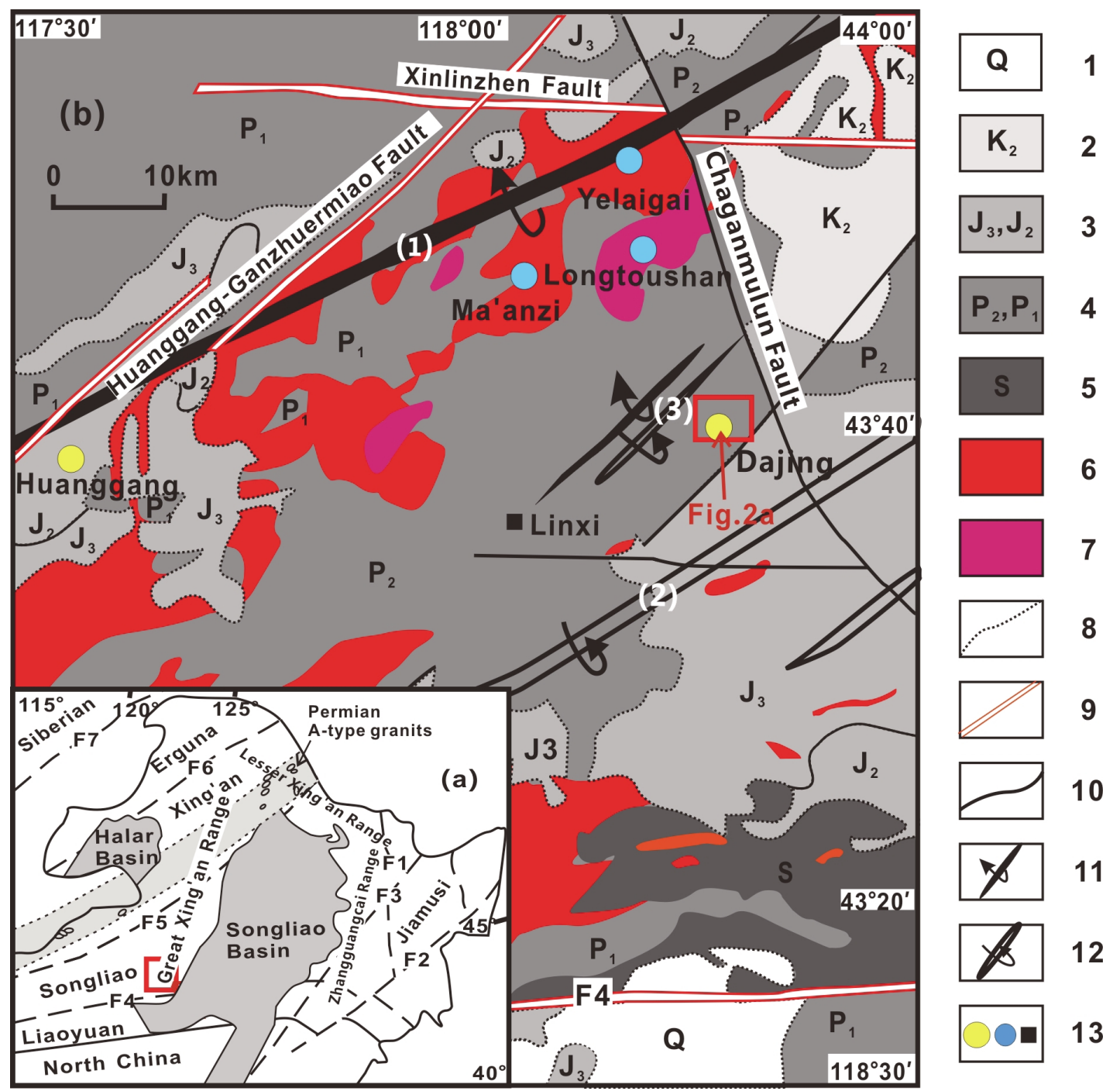

Fig. 1. (a) Tectonic subdivisions of NE China (after Wu et al., 2011); (b) Regional geological map in the Linxi Town of the Southern Great Xing' an Range (after Liu et al., 2001). F1: Mudanjiang; F2: Dunhua-Mishan; F3: Yitong-Yilan; F4: XilamulunChangchun; F5: Hegenshan-Heihe; F6: Tanyuan-Xiguitu; F7: Mongol-Okhotsk; (1) Huangangliao-Ganzhuermiao overturned anticline; (2) Linxi-Taohaiyingzi overturned syncline; (3) Sangmugou-Guandi overturned syncline. 1-Quaternary strata; 2Upper Cretaceous strata; 3-Upper Jurassic and Middle Jurassic strata; 4-Upper Permian Linxi Formation and Lower Permian Huanggangliang Formation strata; 5-Silurian strata; 6-Mesozoic granitoids; 7-Late Paleozoic granitoids; 8-Unconformity geological boundary; 9-Deep faults; 10-Faults; 11-Overturned anticline; 12-Overturned syncline; 13-Deposit, intrusive location and toponym.

Erguna, the central Xing' an and Songliao, and the southeastern Liaoyuan terranes (Fig. 1a). The Xing'an terrane contains the northern Great Xing' an Range and the Halar Basin, whereas the Songliao terrane is split into the Lesser Xing'an Range in the north, the Songliao Basin in the center, the Zhangguangcai Range in the east, and the southern Great Xing' an Range in the west. The southern Great Xing' an Range is located in central NE China and is bounded to the north by the Hegenshan-Heihe suture and to the south by the Xilamulun-Changchun suture (Fig. 1a).

Eastern Inner Mongolia, the southern Great Xing'an Range, and the northern margin of the North China Plate, as well as a number of other areas, underwent postorogenic and intraplate extension after the late Permian (290-260 Ma, Shao et al., 2005; Wu et al., 2002) collision between the North China Plate and the Xingmeng Orogenic Belt; this tectonism also exposes significant volumes of A-type granites along the Hegenshan suture (F5 in Fig. 1a). The Mongol-Okhotsk Ocean ultimately 


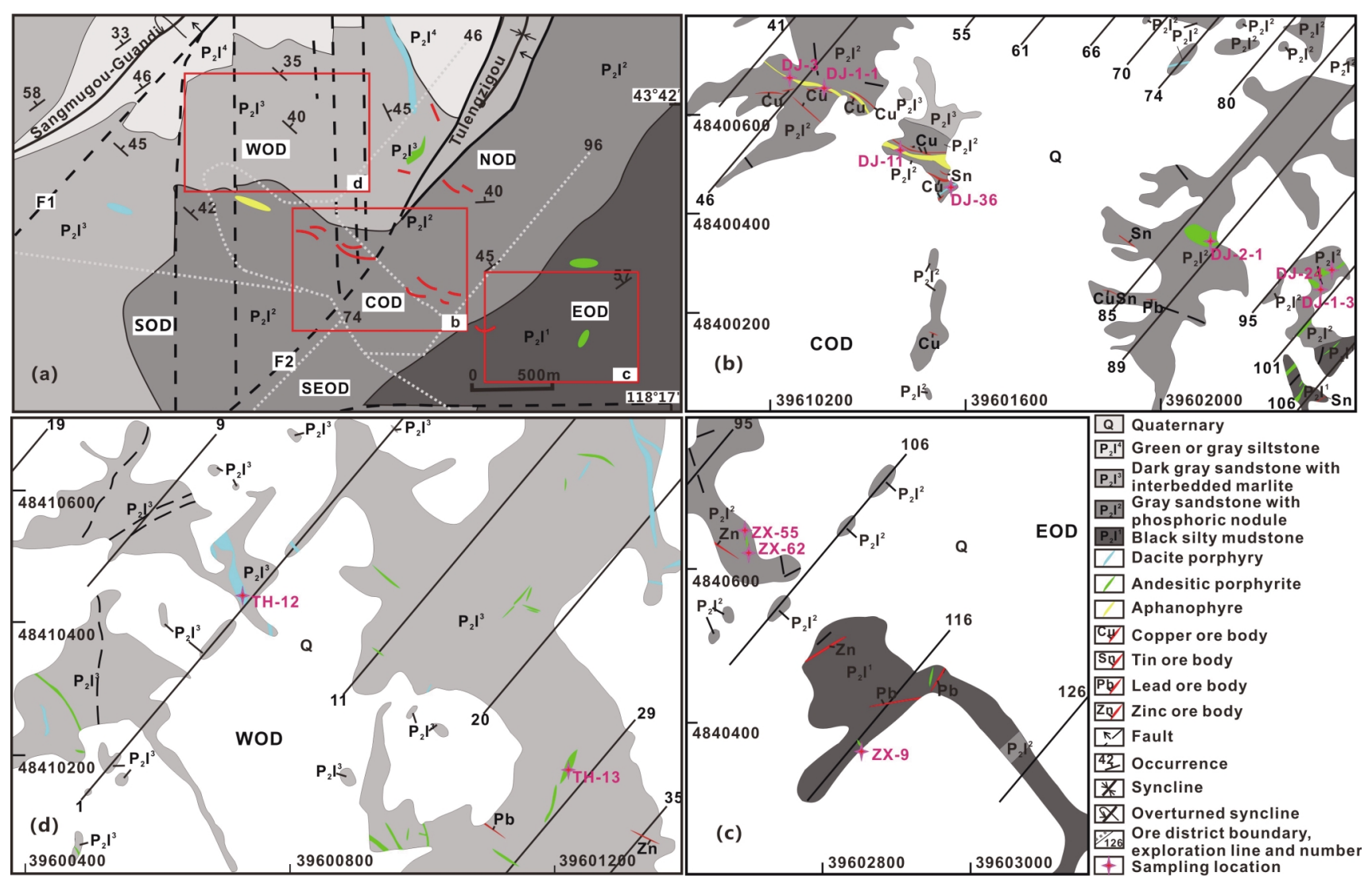

Fig. 2. (a) Geological sketch map of the Dajing deposit; (b) Geological map of Central ore district; (c) Geological map of East ore district; (d) Geological map of West ore district (a is modified from Wang et al., 2001, b, c, and d are modified from LBGMR, 1976). COD: Central ore district of Dajing deposit; WOD: Western ore district of Dajing deposit; EOD: Eastern ore district of Dajing deposit; NOD: Northern ore district of Dajing deposit; SOD: Southern ore district of Dajing deposit; SEOD: Southeastern ore district of Dajing deposit.

closed during the late Jurassic ( 160 Ma, Meng, 2003), an event that was associated with significant magmatism and volcanism within the northern Great Xing' an Range, northeastern Mongolia, the southern margin of the Siberia Plate, and other regions. Middle Jurassic to Early Cretaceous volcanic rocks are widespread throughout the northeastern Great Xing' an Range (Sun et al., 2011). Previous research has indicated that initial subduction of the Paleo-Pacific Plate began in the Early Jurassic, with subduction occurring until the Late Jurassic-Early Cretaceous ( $140 \mathrm{Ma})$. This subduction caused a regional transformation in tectonic setting from compression to extension throughout eastern China, leading to large-scale Early Cretaceous (140-120 Ma) magmatism, volcanism, and mineralization in this area (Mao et al., 2005).

The Dajing deposit is located in Linxi Town, Inner Mongolia (Fig. 1b). The geology of this area, with the exception of Quaternary cover, is dominated by Permian and Jurassic units with minor Silurian and Cretaceous rocks (Fig. 1b). The Silurian units are the oldest in the study area and are dominantly gneisses and schists, whereas the Permian units include the lower Huanggangliang Formation and the upper Linxi Formation; the former is dominated by marble, slate, and sandstone, whereas the latter consists of grey-black siltstones intercalated with fine-grained sandstones that contain phosphatic nodules and bands. The Jurassic (Manketouebo Formation) and the Cretaceous units in this area are dominated by rhyolites, volcaniclastic rocks, and rhyolitic tuffs (Liu et al., 2001).

The study area contains a number of well-developed regional-scale faults and folds, including the deep-seated NE-SW-trending Huanggang-Ganzhuermiao Fault in the northwest of the study area, the deep-seated E-W-trending Xinlinzhen and Xilamulun (F4 in Fig. 1b) faults in the north and south of the study area, respectively, and the NW-SE-trending Chaganmulun Fault in the east. The area contains both primary and secondary folds, including the overturned Huangangliao-Ganzhuermiao anticline ((1) in Fig. 1b) and the overturned Linxi-Taohaiyingzi syncline 


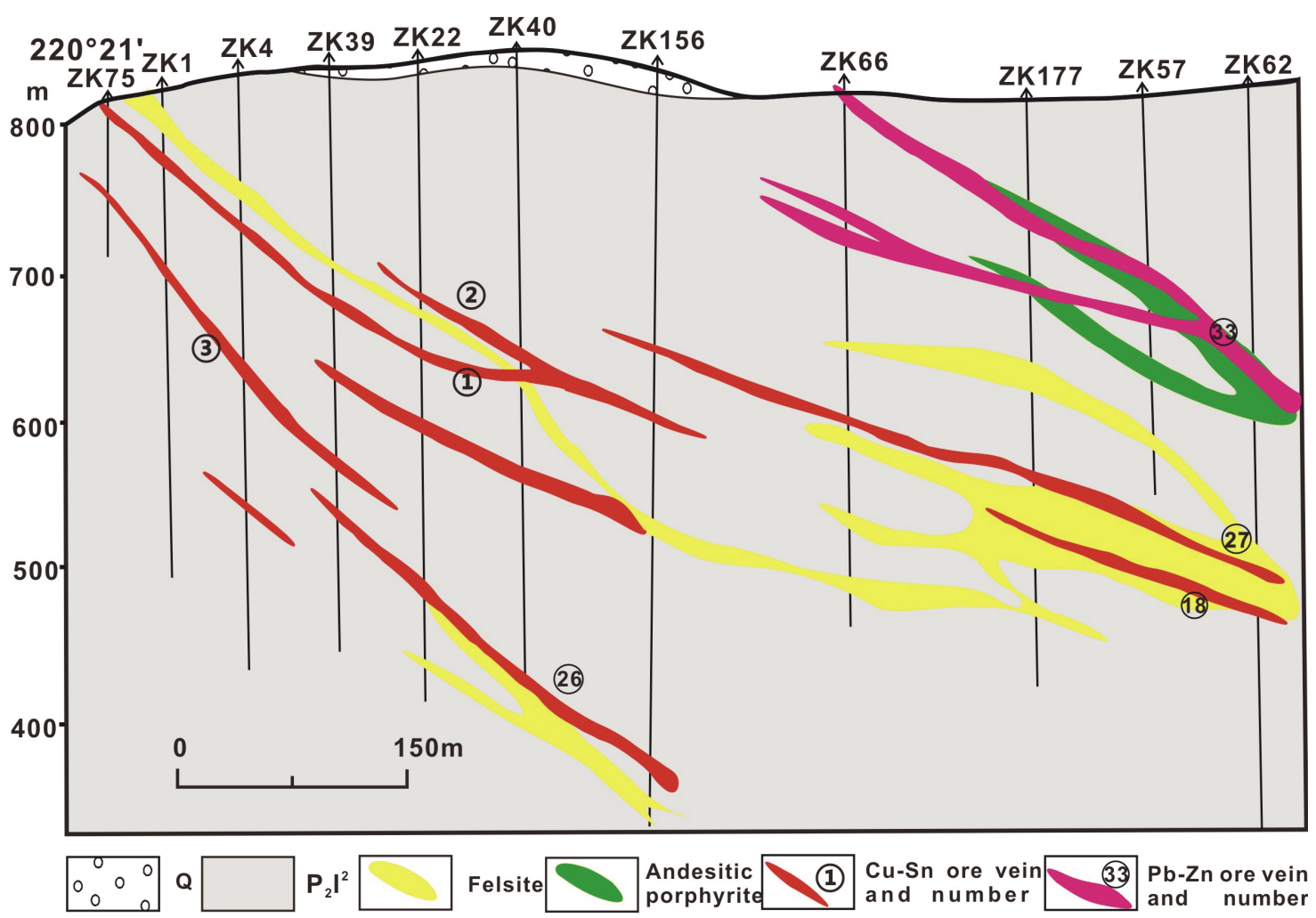

Fig. 3. Profile map of exploration line No. 46 in Dajing deposit (Zhang, 1993).

((2) in Fig. 1b). Magmatic rocks, including Mesozoic (e.g., Ma' anzi and Yelaigai intrusions) and late Paleozoic (e.g., Longtoushan intrusion; Fig. 1b) granitoids are widespread throughout the area. Mesozoic granitoids are dominantly $\mathrm{K}$-feldspar granites and porphyritic granites, whereas the rare late Paleozoic granitoids are dominantly quartz diorites and granodiorites (Liu et al., 2001).

\section{DEPOSIT GEOLOGY}

The study area is dominated by the late Permian Linxi Formation $\left(\mathrm{P}_{2}\right.$ l, Fig. 2a) that outcrops in a belt that strikes NW-SW, with some offshoots that strike NE-SW. Research by LBGMR (1976) suggests that these freshwater and lacustrine sedimentary rocks $\left(\mathrm{P}_{2} \mathrm{l}\right)$ are subdivided from bottom to top into a black silty mudstone member $\left(\mathrm{P}_{2} 1^{1}\right)$, a grey fine- to medium-grained sandstone member containing phosphoric nodules or bandings $\left(\mathrm{P}_{2} 1^{2}\right)$, a dark grey fine-grained sandstone member with interbedded marl horizons $\left(\mathrm{P}_{2}{ }^{3}\right)$, and a green or grey siltstone member $\left(\mathrm{P}_{2} 1^{4}\right)$. The area is dominated by a weakly folded monoclinal structure, with the exception of the Tulengzigou syncline and the overturned SangmugouGuandi syncline (Fig. 2a), which in turn is controlled by the overturned Linxi-Taohaiyingzi syncline ((2) in Fig. 1b) in this area. The area has four distinct fracture sets that are oriented NE-SW, N-S, NW-SE, and E-W; of these, the NW-SE-trending faults are associated with some of the subvolcanic rocks and mineralized veins (Fig. 2a).

No intrusive are exposed at the surface or have been encountered during drilling within the Dajing deposit, and the nearest intrusives are the granitoids of the Linxi district, namely the Ma'anzi, Longtoushan, and Yelaigai intrusions, which are located some $9 \mathrm{~km}$ to the northwest of the study area (Fig. 1b). A number of hypabyssal subvolcanic dykes crosscut the Linxi Formation $\left(\mathrm{P}_{2} \mathrm{l}\right.$; Fig. $2 a)$, and three main types of subvolcanic rocks have been identified within the Dajing deposit: a felsite, a porphyritic andesite, and a porphyritic dacite. The felsite is located within the central ore district (COD) in the study area, strikes NW-SE, dips to the NE, outcrops over an area more than $100 \mathrm{~m}$ long but only $0.3 \mathrm{~m}$ wide (Fig. 2b), and stratigraphically overlies $\mathrm{Cu}-\mathrm{Sn}$ veins within the deposit. The porphyritic andesite outcrops in the eastern part of the COD, the western ore district (WOD), and the eastern ore district (EOD); this rock outcrops over an area more than $600 \mathrm{~m}$ long and several centimeters to several meters wide, strikes NW-SE, and dips to the NE (Figs. $2 \mathrm{~b}$ and $2 \mathrm{c}$ ). This rock hosts mineralized $\mathrm{Pb}-\mathrm{Zn}$ veins within the deposit. The porphyritic dacite generally outcrops in the western COD and the WOD, and is present 

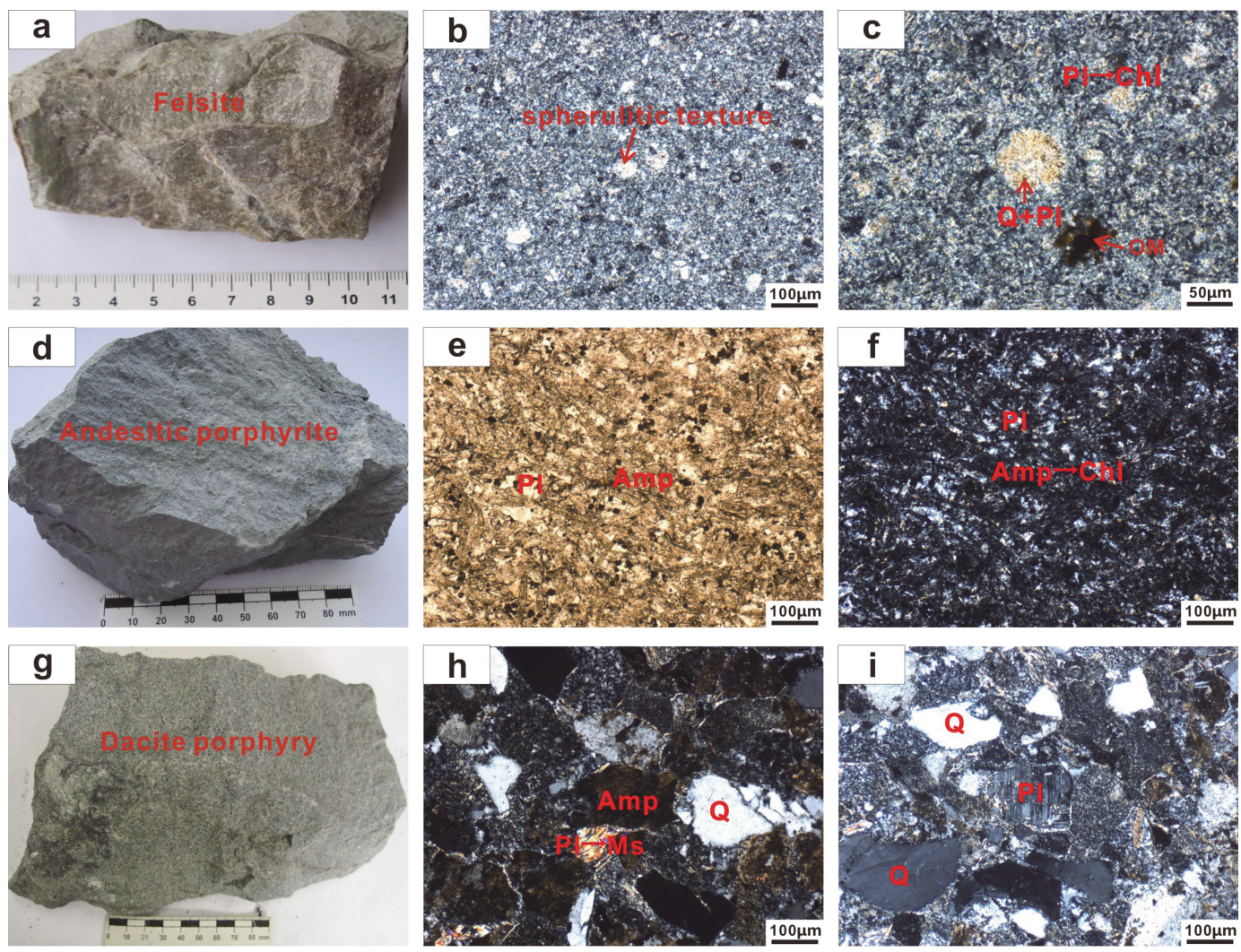

Fig. 4. Hand specimens and photomicrographs of subvolcanic rocks. (a) Hand specimen of felsite; (b) Spherulitic texture of felsite; (c) Spherulite is composed of quartz and plagioclase $(Q+P l)$, plagioclase was altered to chlorite $(P l \rightarrow C h l)$, felsite also has some opaque minerals (OM); (d) Hand specimen of porphyritic andesite; (e), (f) Matrix of porphyritic andesite is hyalopilitic in texture, including amphibole (Amp) and plagioclase (Pl); $(f)$ Amphibole was also altered to chlorite (Amp $\rightarrow$ Chl); (g) Hand specimen of porphyritic dacite; (h) Amphibole phenocryst, plagioclase matrix was altered to muscovite (Pl $\rightarrow M s) ;(i) P l a g i o c l a s e$ phenocryst shows polysynthetic twinning, and quartz phenocryst is xenomorphic-granular.

as a series of $10-800 \mathrm{~m}$ long and $2-20 \mathrm{~m}$ wide dykes that are split into two groups: one striking $\mathrm{N} 40^{\circ}$ and one striking $\mathrm{N} 320^{\circ}$ (Figs. 2b and 2d).

The Dajing deposit is a vein-type polymetallic Sn deposit that consists of $>330$ ore veins, the majority of which do not crop out. These veins strike NW-SE or WNWESE and dip between $25^{\circ}$ and $75^{\circ}$ to the north (LBGMR, 1976). The veins crosscut Permian units at low angles $\left(<20^{\circ}\right)$ and are present as veins, vein networks, and composite veins within either Permian or subvolcanic rocks. These veins are dominated by chalcopyrite, cassiterite, sphalerite, galena, pyrite, pyrrhotite, arsenopyrite, acanthite, stephanite, and native silver in a siderite, ankerite, calcite, quartz, sericite, chlorite, and fluorite gangue (Wang, Y. W. et al., 2002, 2006). The veins are associated with weak silicification, and with chlorite, carbonate, and sericite alterations that are generally limited to the areas adjacent to individual veins. Ore textures include euhedral-subhedral, xenomorphic-granular, exsolution, replacement remnant, and skeletal minerali- zation, all of which are within stockwork veins, brecciated, massive, disseminated, and banded ores (Liu et al., 2001).

Crosscutting relationships between ore veins, zonation within ore veins, and paragenetic associations have allowed the identification of three stages of mineralization within the Dajing deposit: (1) a cassiteritearsenopyrite-quartz stage, (2) a pyrite-chalcopyrite sulfide stage, and (3) a $\mathrm{Pb}-\mathrm{Zn}-\mathrm{Ag}$-carbonate stage. The mineralization within the Dajing deposit is also zoned (Zhang, 1993), with $\mathrm{Cu}$ and $\mathrm{Sn}$ enrichments within the felsite-hosted sections of the COD (Figs. 2b and 3), and $\mathrm{Pb}$ and $\mathrm{Zn}$ enrichments within the porphyritic andesitehosted periphery of the deposit (e.g., the eastern WOD and the EOD; Figs. 2c, 2d, and 3).

\section{SAMPLES AND ANALYTICAL METHODS}

Sample description

Three felsite, seven porphyritic andesite, and two 


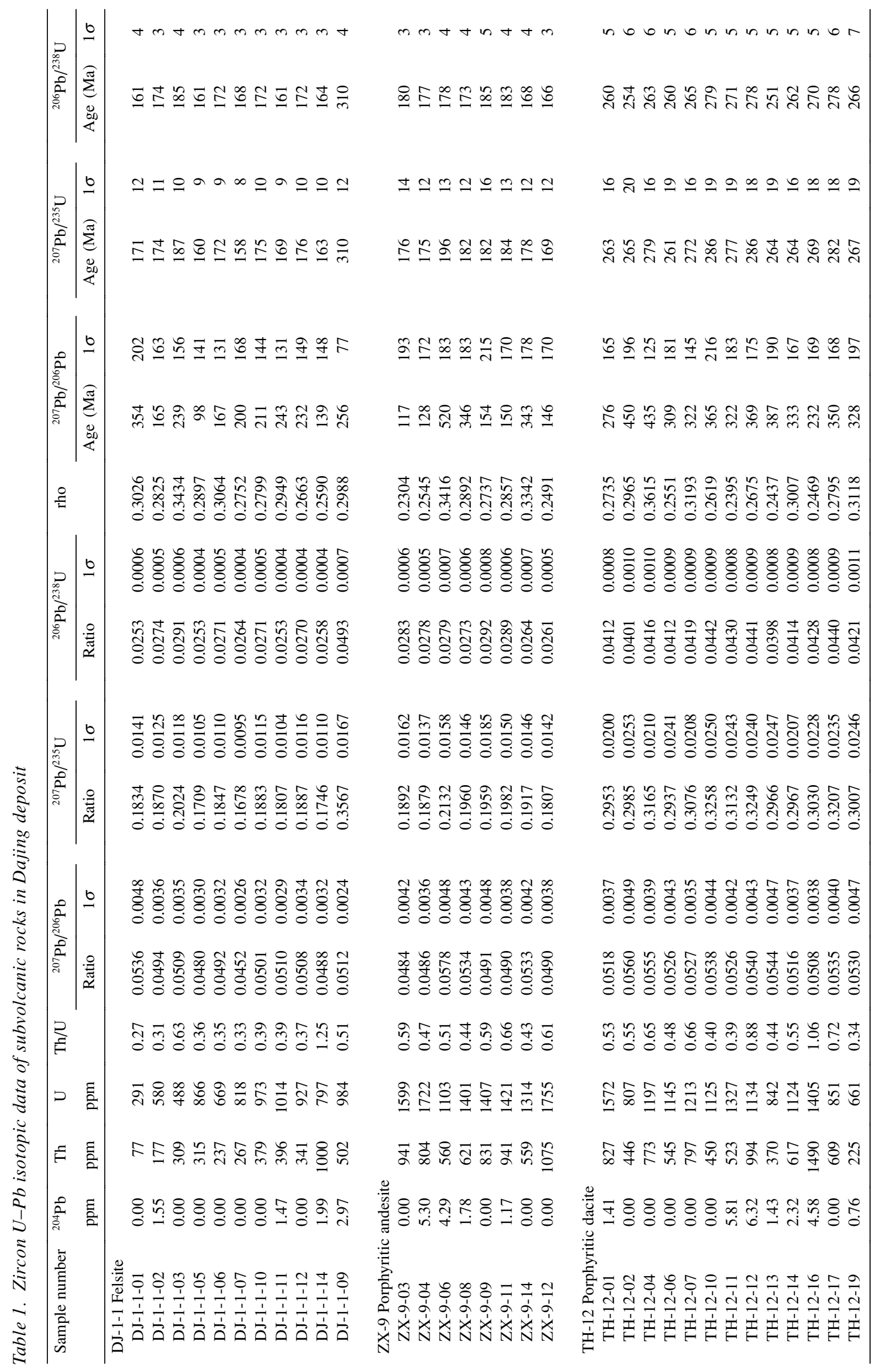



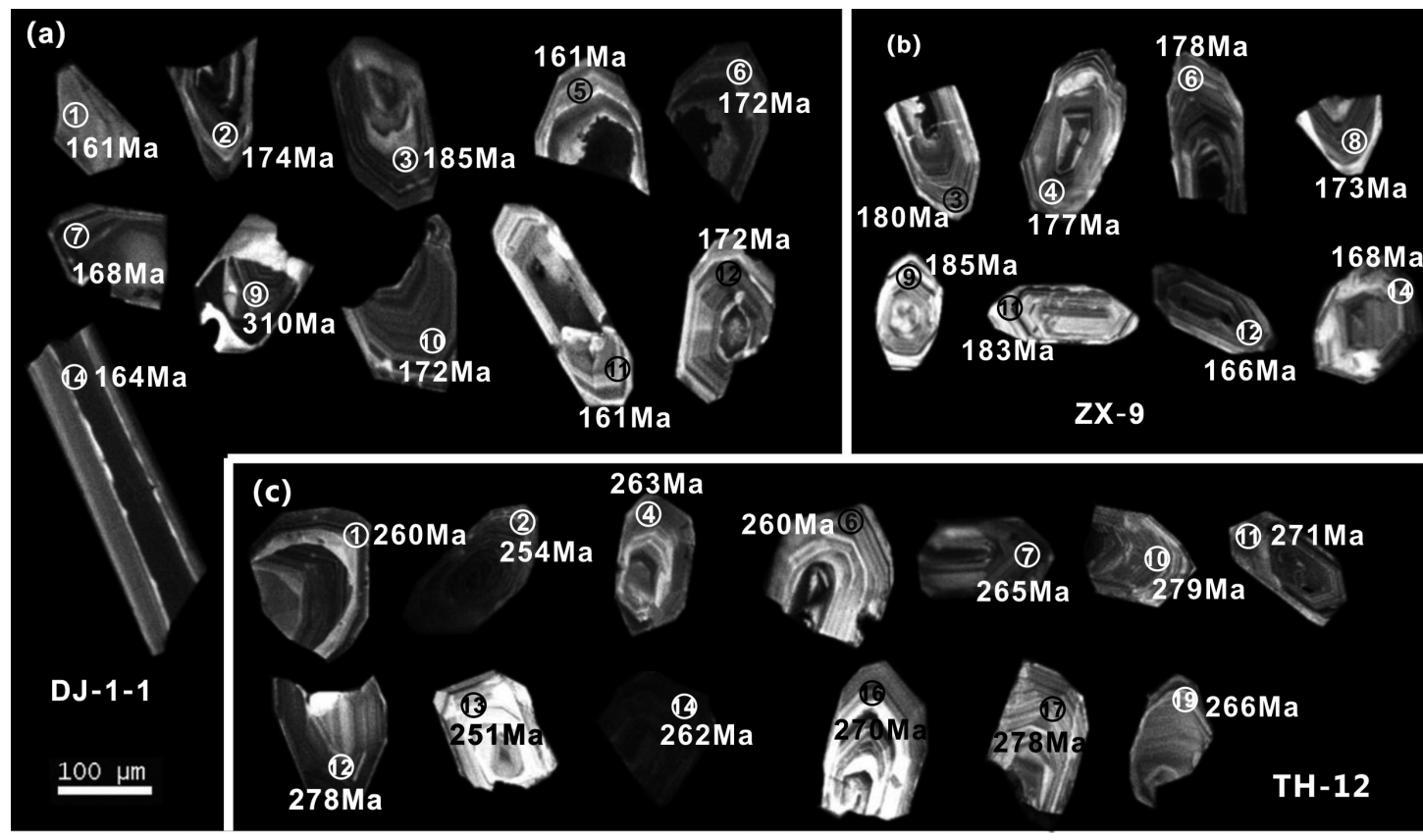

Fig. 5. (a) Selected zircon CL images, dating point, and data of DJ-1-1 for felsite; (b) Selected zircon CL images, dating point, and data of ZX-9 for porphyritic andesite; (c) Selected zircon CL images, dating point, and data of TH-12 for porphyritic dacite.

porphyritic dacite samples were collected from the various ore districts within the Dajing deposit (Figs. 2b-d). The felsite is greyish-white, has felsitic and spherulitic textures, and is massive (Fig. 4a). It contains plagioclase $(50 \%)$, quartz (40\%), and opaque minerals $(10 \%)$, in addition to spherulitic aggregates of plagioclase and quartz that were generated during devitrification (Figs. 4b and $4 \mathrm{c})$, present as small $(<2 \mu \mathrm{m})$ xenomorphic granular crystals that are partially altered to chlorite, whereas the quartz is xenomorphically granular but is generally $<1.5 \mu \mathrm{m}$ in size and is unaltered and free of inclusions.

The porphyritic andesite is dark grey, porphyritic, and massive (Fig. 4d). It contains plagioclase $(2-5 \mathrm{~mm} ; 2 \%-$ $3 \%$ abundance) and amphibole (4-6 $\mathrm{mm} ; 1 \%-2 \%)$ phenocrysts in a hyalopilitic matrix (Figs. $4 \mathrm{e}$ and $4 \mathrm{f}$ ) that has a $0.5-1 \mathrm{~mm}$ grain size, and contains amphibole $(\geq 65 \%)$, plagioclase $(20 \%-25 \%)$, biotite $(2 \%-3 \%)$, quartz $(5 \%)$, and magnetite $(2 \%-3 \%)$. The plagioclase is euhedral to subhedral and tabular, whereas the amphibole is subhedral, cylindrical, and is slightly altered to chlorite (Fig. 4f), the biotite is scaly, and the quartz is generally present as interstitial crystals between plagioclase.

The porphyritic dacite is greyish-green, porphyritic, and massive (Fig. 4g), and contains plagioclase (0.1-0.3 $\mathrm{mm}, 30 \%)$, amphibole $(0.1-0.3 \mathrm{~mm}, 20 \%)$, and quartz $(0.1-0.25 \mathrm{~mm}, 20 \%)$ phenocrysts. Plagioclase within the unit is euhedral, tabular, contains polysynthetic twins (Fig. $4 \mathrm{i}$ ), and is partially altered to muscovite, whereas the amphibole is reddish brown and xenomorphic (Fig. 4h), and the quartz is xenomorphic and granular. This unit has a cryptocrystalline matrix that contains plagioclase (10\%), quartz $(10 \%)$, biotite $(5 \%)$, and amphibole $(5 \%)$.

\section{Zircon LA-ICP-MS U-Pb dating}

Zircons were separated from three subvolcanic rock samples during this study, namely samples DJ-1-1 (felsite), ZX-9 (porphyritic andesite), and TH-12 (porphyritic dacite), using conventional heavy liquid and magnetic techniques at the Langfang Regional Geological Survey, Hebei Province, China. Representative zircons were handpicked under a binocular microscope, were mounted in an epoxy resin disc, and then polished and coated with gold film prior to analysis. Zircons were imaged under transmitted and reflected light and cathodoluminescence using a JXA-8100 instrument fitted with a MonoCL3 setup, employing an acceleration voltage of $1-30 \mathrm{kV}$ and with a $200-900 \mathrm{~nm}$ spectrum to reveal external and internal structures. These zircons were analyzed using laser ablation (LA) at the State Key Laboratory of Geological Processes and Mineral Resources, China University of Geosciences in Wuhan, China, using an Agilent 7500a inductively coupled plasma-mass spectrometer (ICP-MS), equipped with a $193 \mathrm{~nm}$ excimer laser. Ages were calibrated using a zircon 91500 standard (Wiedenbeck et al., 1995), and an NIST 610 standard was used to optimize trace element concentrations. The analyses used a $24 \mu \mathrm{m}$ diameter spot and followed Liu $e t$ al. $(2008,2010)$. No common lead correction was applied 

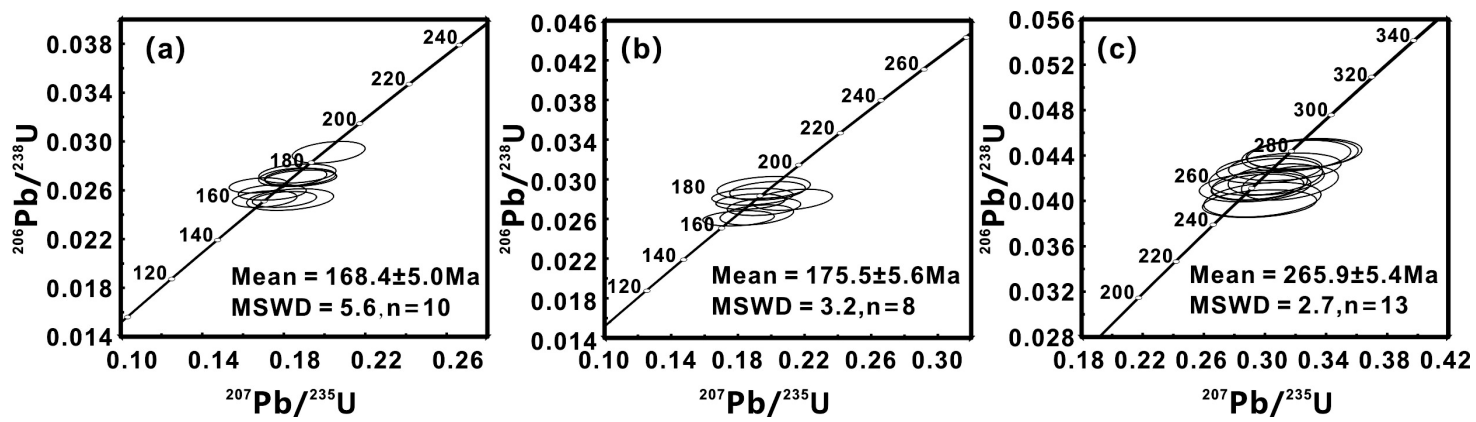

Fig. 6. (a) LA-ICP-MS U-Pb concordia diagrams and weighted mean ${ }^{206} P b /{ }^{238} U$ age for zircon grains DJ-1-1 (felsite); (b) LA$I C P-M S U-P b$ concordia diagrams and weighted mean ${ }^{206} \mathrm{~Pb} /{ }^{238} U$ age for zircon grains $Z X-9$ (porphyritic andesite); (c) LA-ICPMS U-Pb concordia diagrams and weighted mean ${ }^{206} \mathrm{~Pb} /{ }^{238} \mathrm{U}$ age for zircon grains $\mathrm{TH}-12$ (porphyritic dacite).

to the data because of the very low ${ }^{204} \mathrm{~Pb}$ counts obtained during analysis and poor analytical precision of ${ }^{204} \mathrm{~Pb}$. Ages were calculated using ICPMSDataCal software (ver9.0; China University of Geosciences; Liu et al., 2008), and Concordia diagrams were constructed using Isoplot/Ex ver3.7 (Ludwig, 2003). Zircon trace element composition was calibrated using a GSE-1G standard combined with internal standardization using ${ }^{29} \mathrm{Si}$ (Liu et al., 2010). Errors on individual LA-ICP-MS analyses are quoted at the 95\% ( $1 \sigma)$ confidence level. Measured isotopic ratios and calculated ages for individual analyses are given in Table 1, and representative CL images of the zircons are shown in Fig. 5. The zircons are generally euhedral, colorless, transparent, and elongate to prismatic, and are up to $240 \mu \mathrm{m}$ in diameter. They contain clear oscillatory zoning, and some zircons have clear core-rim textures with dark sector-zoned cores (Fig. 5). Concordia diagrams and weighted mean ages are shown for each sample in Figs. 6a-c.

\section{Major and trace elemental analyses}

The major and trace element compositions of 10 subvolcanic rock samples were determined during this study. Prior to analysis, whole-rock samples were trimmed to remove altered surfaces, before being crushed and then powdered in an agate mill.

Major elements were analyzed using a PAN analytical Axios X-ray fluorescence spectrometer (XRF) at ALS Chemex Co. Ltd. in Guangzhou, China. Before analysis, $0.9 \mathrm{~g}$ of ignited sample was added to $9.0 \mathrm{~g}$ of lithium borate flux $\left(50 \%-50 \% \quad \mathrm{Li}_{2} \mathrm{~B}_{4} \mathrm{O}_{7}-\mathrm{LiBO}_{2}\right)$ before being mixed and fused in an auto-fluxer at temperatures between $1050^{\circ} \mathrm{C}$ and $1100^{\circ} \mathrm{C}$, yielding the melt carried in a flat molten glass disc, and then was analyzed by XRF. The precision of the XRF analyses was better than $5 \%$.

Trace element concentrations were determined using an Elan 9000 ICP-MS instrument at the same lab as was used for XRF analysis. Before analysis, $0.2 \mathrm{~g}$ of sample was added to a lithium metaborate flux $(0.9 \mathrm{~g})$ before the sample was mixed and then fused in a furnace at $1000^{\circ} \mathrm{C}$. The resulting melt was then cooled and dissolved in 100 ml of $4 \% \mathrm{HNO}_{3} / 2 \% \mathrm{HCl}_{3}$ solution, which was then analyzed by ICP-MS. The precision of the ICP-MS analysis at ALS Chemex was better than $10 \%$ for all elements. Major element concentrations are reported as weight percent (wt.\%) and trace element concentrations are reported in $\mathrm{ppm}$.

\section{RESULTS}

\section{Zircon cathodoluminescence images and $U-P b$ data}

The zircons analyzed during this study have Th and $U$ concentrations as follows: felsite sample DJ-1-1 contains zircons with $\mathrm{Th}$ and $\mathrm{U}$ concentrations of 77-1000 and 291-1014 ppm, respectively, yielding an average $\mathrm{Th} / \mathrm{U}$ ratio of 0.47 ; porphyritic andesite sample $\mathrm{ZX}-9$ contains zircons with Th and $U$ concentrations of 559-1075 and 1103-1755 ppm, respectively, yielding an average $\mathrm{Th} / \mathrm{U}$ ratio of 0.54 ; and porphyritic dacite sample TH-12 contains zircons with relatively high Th concentrations (225$1490 \mathrm{ppm}$ ), relatively low $\mathrm{U}$ concentrations (661-1572 $\mathrm{ppm})$, and an average $\mathrm{Th} / \mathrm{U}$ ratio of 0.59 . Wu and $\mathrm{Zheng}$ (2004) determined that magmatic zircons have $\mathrm{Th} / \mathrm{U}$ that are generally $>0.4$; this means that the oscillatory zoning and average $\mathrm{Th} / \mathrm{U}$ ratios $(0.47$ to 0.59$)$ of the zircons analyzed during this study are indicative of a magmatic origin.

Zircons from sample DJ-1-1 are concordant within error and yield a weighted ${ }^{206} \mathrm{~Pb} /{ }^{238} \mathrm{U}$ mean age of 168.4 $\pm 5.0 \mathrm{Ma}(n=10$; Fig. $6 \mathrm{a})$, interpreted to be the crystallization age of the felsite. Zircon DJ-1-1-9 yielded an older ${ }^{206} \mathrm{~Pb} /{ }^{238} \mathrm{U}$ age of $310 \mathrm{Ma}$ (Table 1 ), although this zircon has a sector zoned core that is much darker than the surrounding magmatic rims (Fig. 5), indicating that this zircon was inherited from the source of the magma that formed this unit or from the surrounding wall rocks during intrusion. Samples ZX-9 and TH-12 have weighted ${ }^{206} \mathrm{~Pb} /{ }^{238} \mathrm{U}$ mean ages of $175.5 \pm 5.6(n=8$; Fig. $6 \mathrm{~b})$ and 


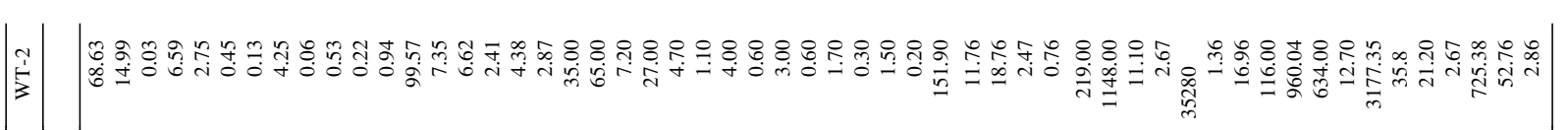

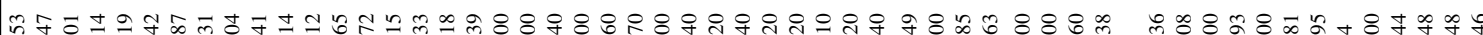

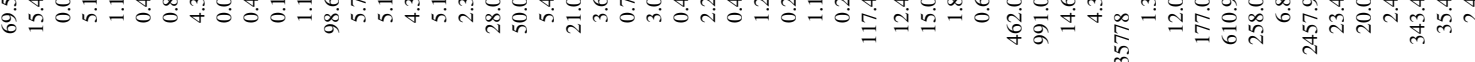

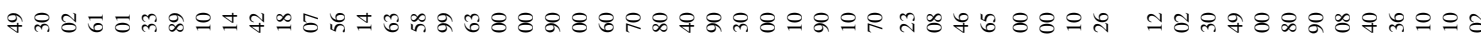

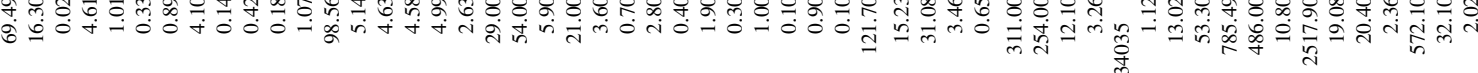

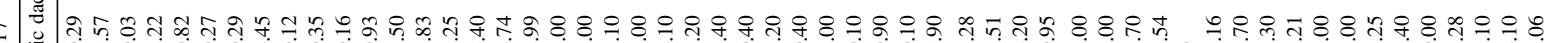

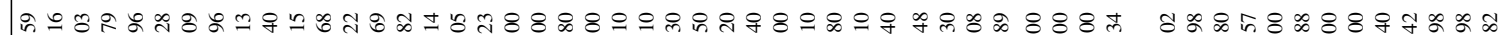

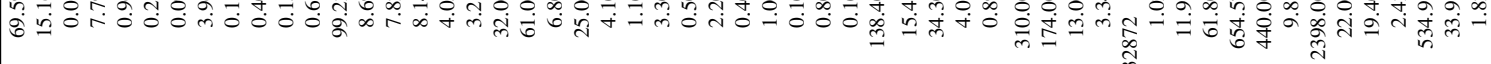

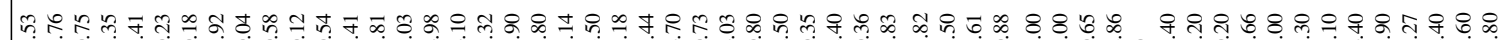

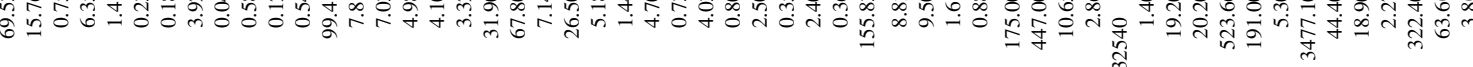

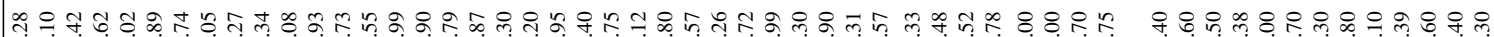

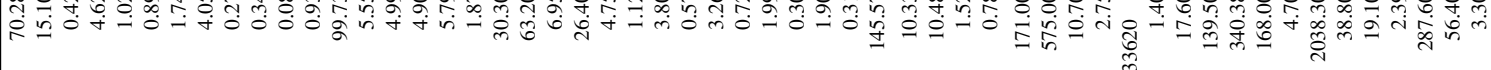

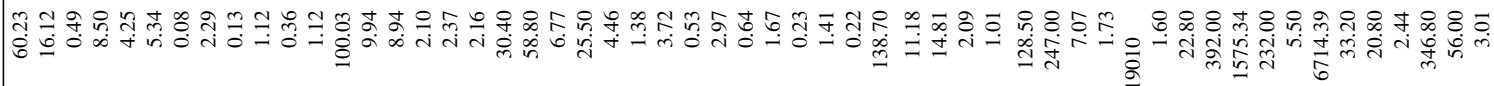

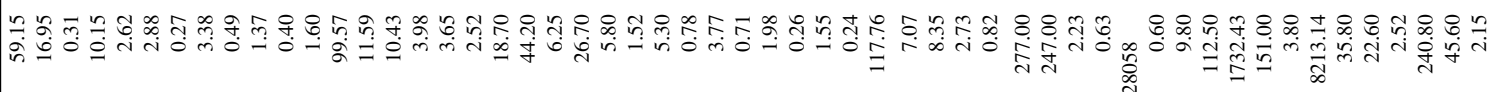

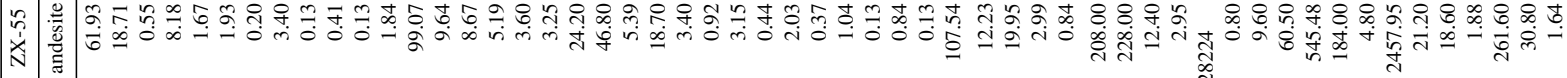

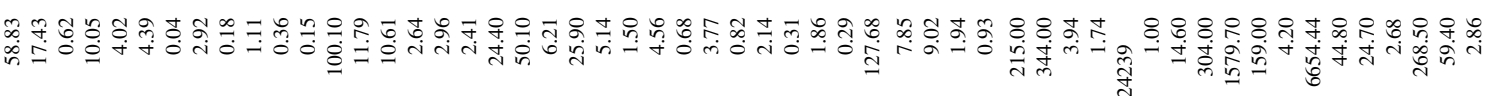

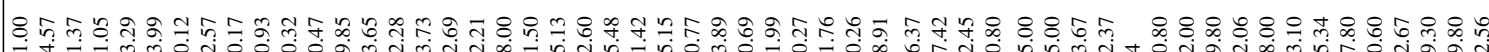

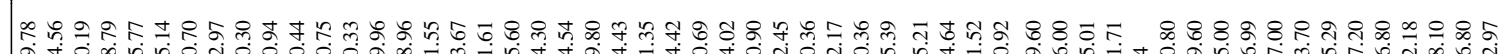

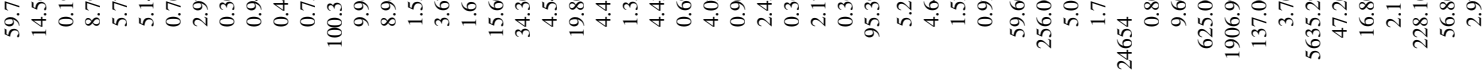

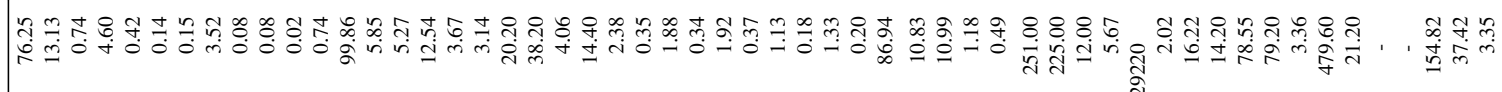

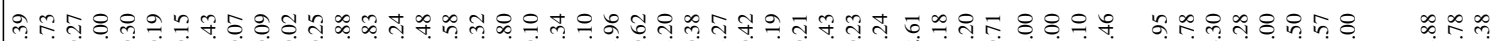

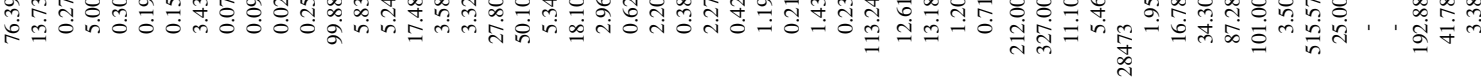

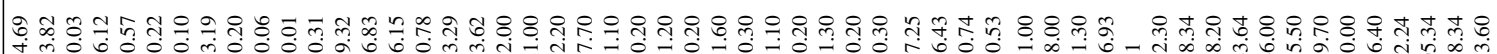

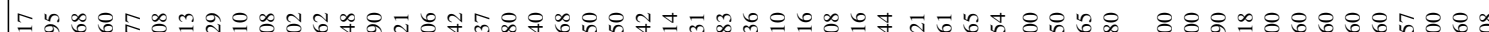

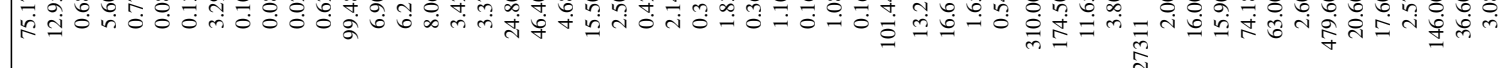

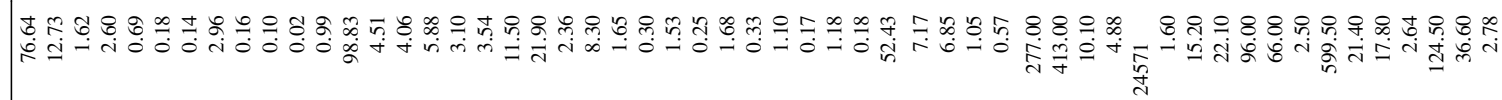



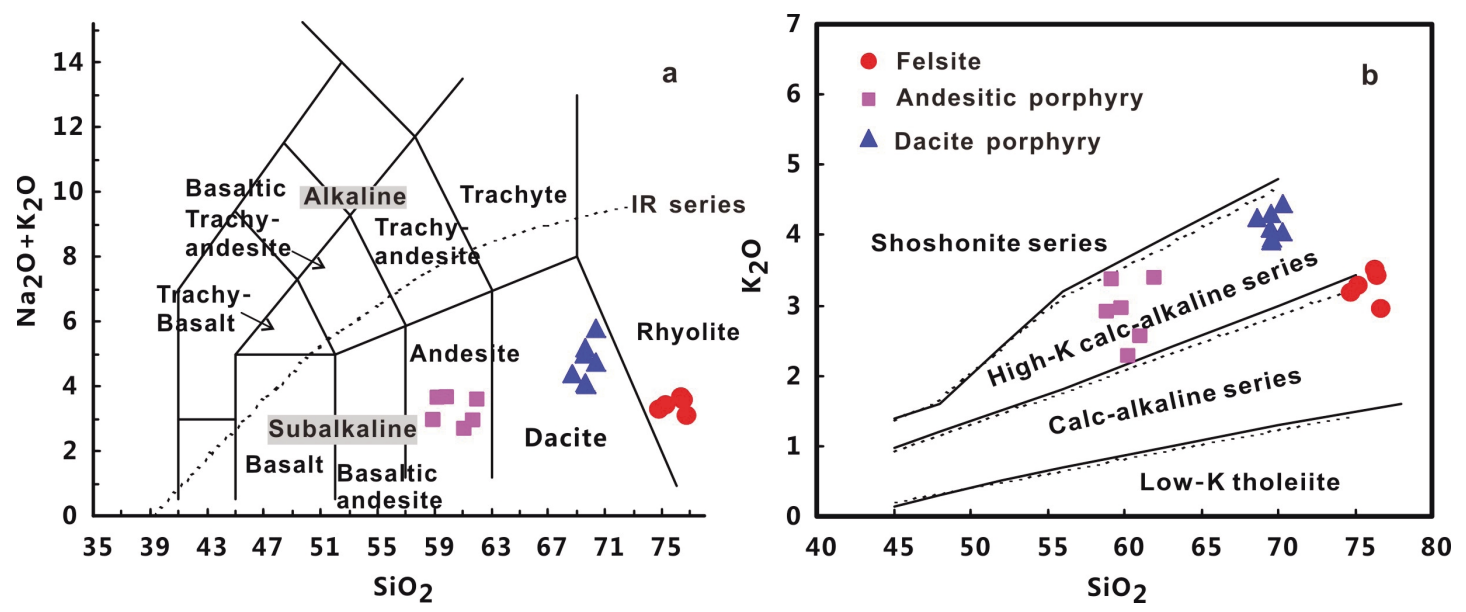

Fig. 7. (a) $\mathrm{Na}_{2} \mathrm{O}+\mathrm{K}_{2} \mathrm{O}$ vs. $\mathrm{SiO}_{2}$ plots (after Le Bas et al., 1986; IR series is from Irvine and Baragar, 1971); (b) $\mathrm{K}_{2} \mathrm{O}$ vs. $\mathrm{SiO}_{2}$ plots (solid line is from Peccerillo and Taylor, 1976; dotted line is from Middlemost, 1985).

$265.9 \pm 5.4 \mathrm{Ma}(n=13$; Fig. $6 \mathrm{c})$, respectively, interpreted to be the crystallization ages of the porphyritic andesite and the porphyritic dacite, respectively.

\section{Major elements}

This study focuses on the major and trace element compositions of 18 samples, including some data from earlier studies (e.g., Zhang et al., 2011; Jiang et al., 2012) in this area (Table 2). The sampling locations for the samples of subvolcanic rocks associated with the Dajing deposit are shown in Figs. 2b-d, and are discussed below.

The felsite samples have higher A/CNK values (3.14 to 3.62) than samples from the porphyritic andesite (1.61 to 3.25 ) and the porphyritic dacite (1.87 to 3.32 ), with the three A/CNK values indicative of aluminum oversaturation. The porphyritic dacite samples have $\mathrm{K}_{2} \mathrm{O}$ concentrations $(3.92 \mathrm{wt} . \%-4.45 \mathrm{wt} . \%)$ that appear to correlate with loss on ignition (LOI) values $(0.54 \mathrm{wt} . \%-$ $1.12 \mathrm{wt} . \%$; Table 2), indicating that these samples may have undergone muscovite alteration, a hypothesis that was confirmed by petrographic observation (Fig. 4h). The $\mathrm{MgO}$ concentrations of the porphyritic andesite samples (1.67wt.\%-5.77wt.\%) correlate with LOI values (0.15wt.\%-1.84wt.\%; Table 2), indicating that these samples may have undergone chlorite alteration, again a hypothesis that is corroborated by petrographic observations (Fig. 4f). The felsite samples have $\mathrm{FeO}$ concentrations (2.60wt.\%-6.12wt.\%) that correlate with the LOI values ( 0.25 wt. $\%-0.99$ wt.\%; Table 2$)$, indicating that these samples have undergone partial chlorite alteration, as confirmed by petrography (Fig. 4c).

The felsite, porphyritic andesite, and porphyritic dacite samples plot in the rhyolite, andesite, and dacite fields of a $\mathrm{SiO}_{2}$ vs. $\mathrm{K}_{2} \mathrm{O}+\mathrm{Na}_{2} \mathrm{O}$ diagram, respectively (Fig. 7a). In addition, the felsite samples are transitional between
high-K calc-alkaline and calc-alkaline in a $\mathrm{SiO}_{2}$ vs. $\mathrm{K}_{2} \mathrm{O}$ diagram (Fig. 7b), whereas the porphyritic andesite and porphyritic dacite samples are dispersed within the high$\mathrm{K}$ calc-alkaline field. Harker diagrams (Fig. 8) indicate that the $\mathrm{Al}_{2} \mathrm{O}_{3}, \mathrm{CaO}, \mathrm{MgO}$, and $\mathrm{FeO}^{\mathrm{T}}$ concentrations of these samples negatively correlate with $\mathrm{SiO}_{2}$ concentrations, whereas $\mathrm{K}_{2} \mathrm{O}$ concentrations positively correlate with $\mathrm{SiO}_{2}$. In addition, the high $\mathrm{K}_{2} \mathrm{O}$ concentrations of the porphyritic dacite samples are indicative of the influence of muscovite, meaning that these samples do not follow linear trends.

\section{Trace elements}

Although the samples of all three subvolcanic rocks have somewhat similar REE patterns that are characterized by enrichments in the LREE relative to HREE (Figs. $9 \mathrm{a}, 9 \mathrm{c}$, and 9e), there are also some differences in the REE systematics of these samples (Table 2).

The felsite samples are characterized by low $\Sigma$ REE $(50.30-113.24 \mathrm{ppm}),(\mathrm{La} / \mathrm{Lu})_{\mathrm{N}}(6.43-16.61)$, and $(\mathrm{Gd} /$ $\mathrm{Lu})_{\mathrm{N}}(0.74-1.65)$ values compared with $\sum$ REE (95.39$138.70 \mathrm{ppm}),(\mathrm{La} / \mathrm{Lu})_{\mathrm{N}}(4.64-19.95)$, and $(\mathrm{Gd} / \mathrm{Lu})_{\mathrm{N}}(1.52-$ 2.99 ) values for samples of the porphyritic andesite. The porphyritic dacite samples have the highest $\sum$ REE $(117.40-155.83 \mathrm{ppm}),(\mathrm{La} / \mathrm{Lu})_{\mathrm{N}}(9.50-34.30)$, and $(\mathrm{Gd} /$ $\mathrm{Lu})_{\mathrm{N}}(1.52-4.20)$ values. In addition, the felsite samples have more significantly negative $\mathrm{Eu}$ anomalies $(\delta \mathrm{Eu}=$ 0.49 to 0.71$)$ than the porphyritic andesite $(\delta \mathrm{Eu}=0.80$ to 1.01 ) and porphyritic dacite ( $\delta \mathrm{Eu}=0.63$ to 0.95 ) samples.

Primitive-mantle-normalized trace element variation patterns for the samples vary somewhat (Figs. 9b, 9d, and 9f), with felsite samples having positive $\mathrm{Rb}, \mathrm{U}, \mathrm{Nd}, \mathrm{Zr}$, and $\mathrm{Hf}$ anomalies, and negative $\mathrm{Ba}, \mathrm{Sr}, \mathrm{P}$, and $\mathrm{Ti}$ anomalies, whereas porphyritic andesite samples are character- 

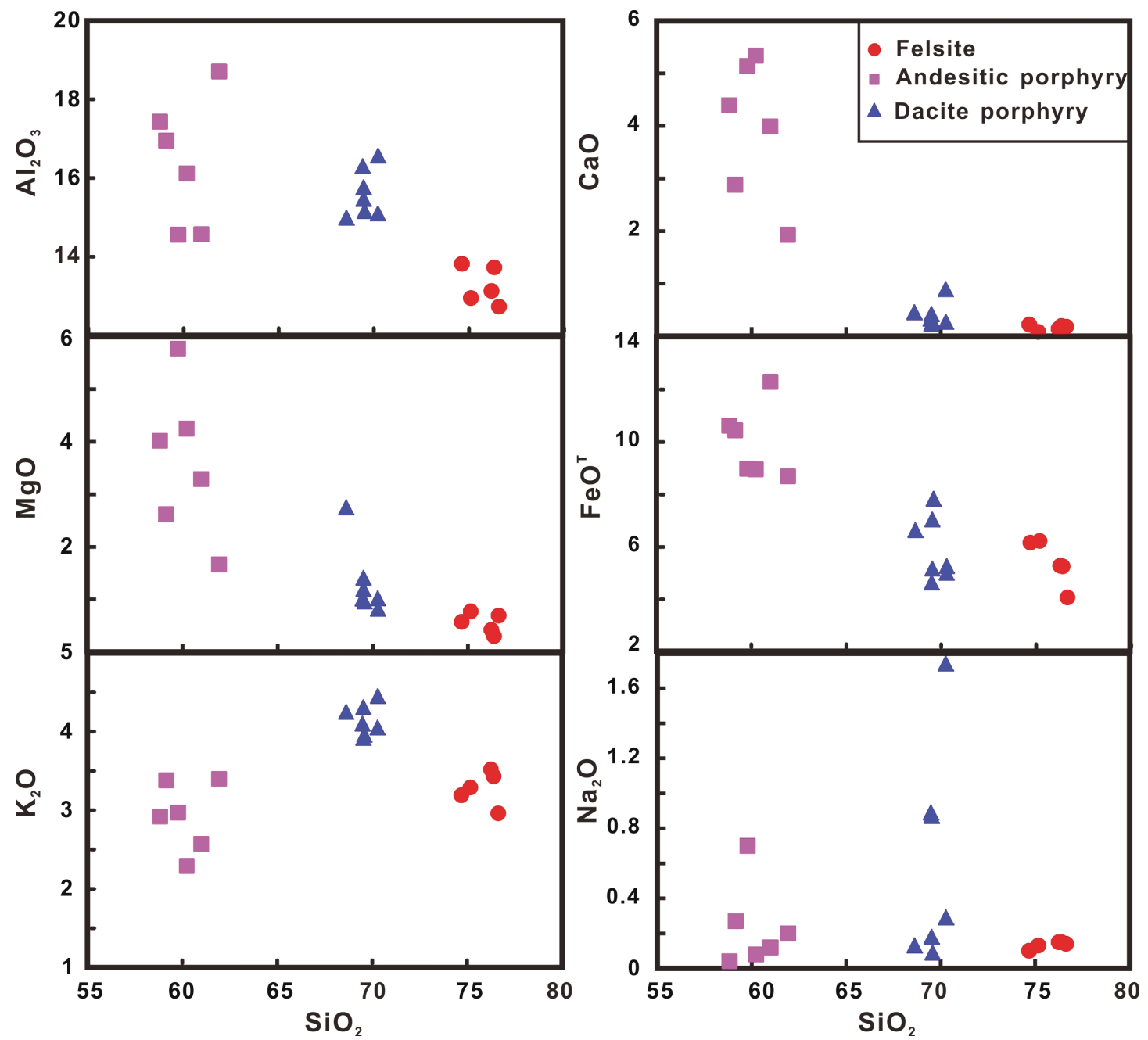

Fig. 8. Harker diagrams of the subvolcanic rocks in Dajing deposit, Southern Great Xing'an Range, NE China.

ized by positive $\mathrm{Rb}$ and $\mathrm{K}$ anomalies and a negative $\mathrm{Ba}$ anomaly. In comparison, the porphyritic dacite samples are characterized by positive $\mathrm{Rb}, \mathrm{Zr}$, and $\mathrm{Hf}$ anomalies, and negative $\mathrm{Ba}, \mathrm{Sr}, \mathrm{P}$, and $\mathrm{Ti}$ anomalies. In addition, felsite, porphyritic andesite, and porphyritic dacite samples plot in fractionated I-type, unfractionated I-type, and A-type granite fields, respectively, in $\mathrm{Zr}$ vs. $10000 \mathrm{Gal} /$ $\mathrm{Al}$ and $\mathrm{FeO}^{\mathrm{T}} / \mathrm{MgO}$ vs. $\mathrm{Zr}+\mathrm{Nd}+\mathrm{Ce}+\mathrm{Y}$ diagrams (Figs. $10 \mathrm{a}$ and $10 \mathrm{~b}$ ), and the porphyritic dacite samples plot in the $\mathrm{A}_{2}$-type granitoid field of a $\mathrm{Nb}$ vs. $\mathrm{Y}$ vs. Ce diagram (Fig. 10c).

\section{DISCUSSION}

Granite geochronology in the Dajing deposit and surrounding region

The zircon $\mathrm{U}-\mathrm{Pb}$ ages of the felsite $(168.4 \pm 5.0 \mathrm{Ma})$ and the porphyritic andesite $(175.5 \pm 5.6 \mathrm{Ma})$ determined during this study, combined with earlier LA-ICP-MS zircon $\mathrm{U}-\mathrm{Pb}$ ages for samples from the Dajing deposit (162 \pm 1 and $170.7 \pm 1.4 \mathrm{Ma}$; Liao et al., 2012; Jiang et al., 2012) indicate that the magmatism in this area was simultaneous with the formation of 190-160 Ma Middle Jurassic granitoids in the Zhangguangcai Range and the Erguna Massif (Fig. 1a; Wu et al., 2011). In addition, numerous other Middle Jurassic granitoids were emplaced in the southern Great Xing' an Range (Table 3), including granitoids in the Chifeng City, Xing'anmeng City, and Xilinguolemeng City areas (e.g., granitoids within the Naoniushan, Lianhuashan, Budunhua, Mengentaolegai, Baiyinnuor, Dashizhai, Jingyang, Ma' anzi, Zhangwuying, and Manketouebo formations), which have ages that cluster around 182 to $160 \mathrm{Ma}$.

The U-Pb age of $265.9 \pm 5.4 \mathrm{Ma}$ for the porphyritic dacite in the study area indicates that this unit formed during the late Permian, and is the equivalent of 290-260 

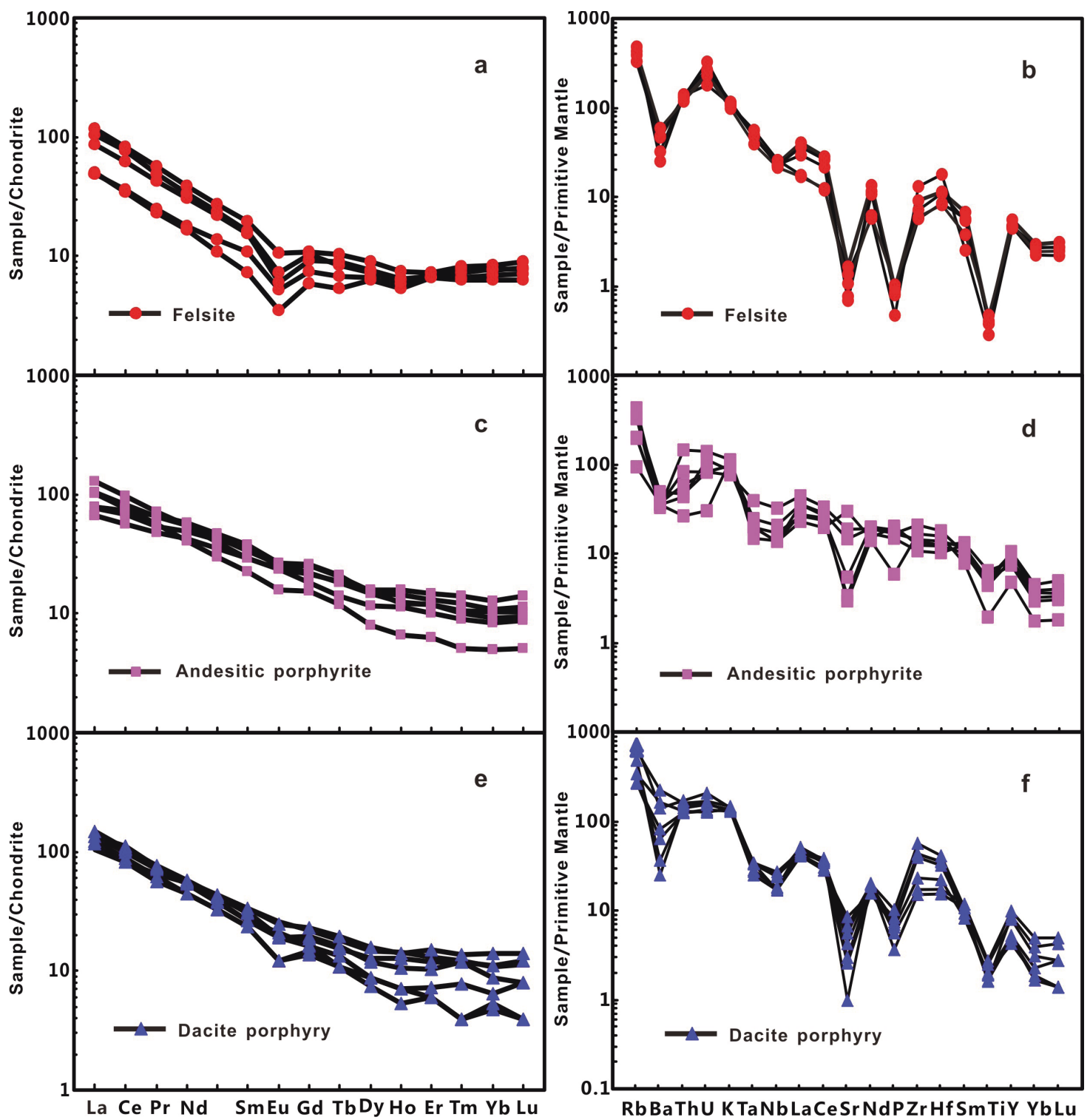

Fig. 9. (a) Chondrite-normalized REE patterns for the felsite in Dajing deposit; (b) Primitive mantle-normalized spider diagrams for the felsite in Dajing deposit; (c) Chondrite-normalized REE patterns for the porphyritic andesite in Dajing deposit; (d) Primitive mantle-normalized spider diagrams for the porphyritic andesite in Dajing deposit; (e) Chondrite-normalized REE patterns for the porphyritic dacite in Dajing deposit; $(f)$ Primitive mantle-normalized spider diagrams for the porphyritic dacite in Dajing deposit; Abundances for Chondrite and Trace element abundances for primitive mantle are after Sun and McDonough (1989).

Ma Permian A-type granites (Wu et al., 2002) of the Lesser Xing'an Range and Inner Mongolia along the Hegenshan-Heihe suture (Fig. 1a).

In summary, the Dajing deposit and adjacent areas underwent three stages (Fig. 11) of magmatism: (1) Late Permian magmatism (280-266 Ma) that formed intrusions such as the Ma'anzi biotite monzogranite to the NW of the Dajing deposit (Fig. 1b; 279.7 Ma; Jiang et al., 2012) and the porphyritic dacite within the Dajing deposit was dated during this study $(265.9 \pm 5.4 \mathrm{Ma})$; (2) Middle
Jurassic magmatism (176-162 Ma), including the formation of the felsite (170.7-162 Ma, Liao et al., 2012; Jiang et al., 2012; this paper) and the porphyritic andesite (175.5 $\pm 5.6 \mathrm{Ma}$ ) that were dated during this study, both of which are within the Dajing deposit; and (3) Early Cretaceous magmatism (146-125 Ma), including the formation of the Ma'anzi, Longtoushan and Yelaigai intrusions (Fig. 1b; 146-125 Ma, Liu et al., 2009) to the NW of the Dajing deposit. 

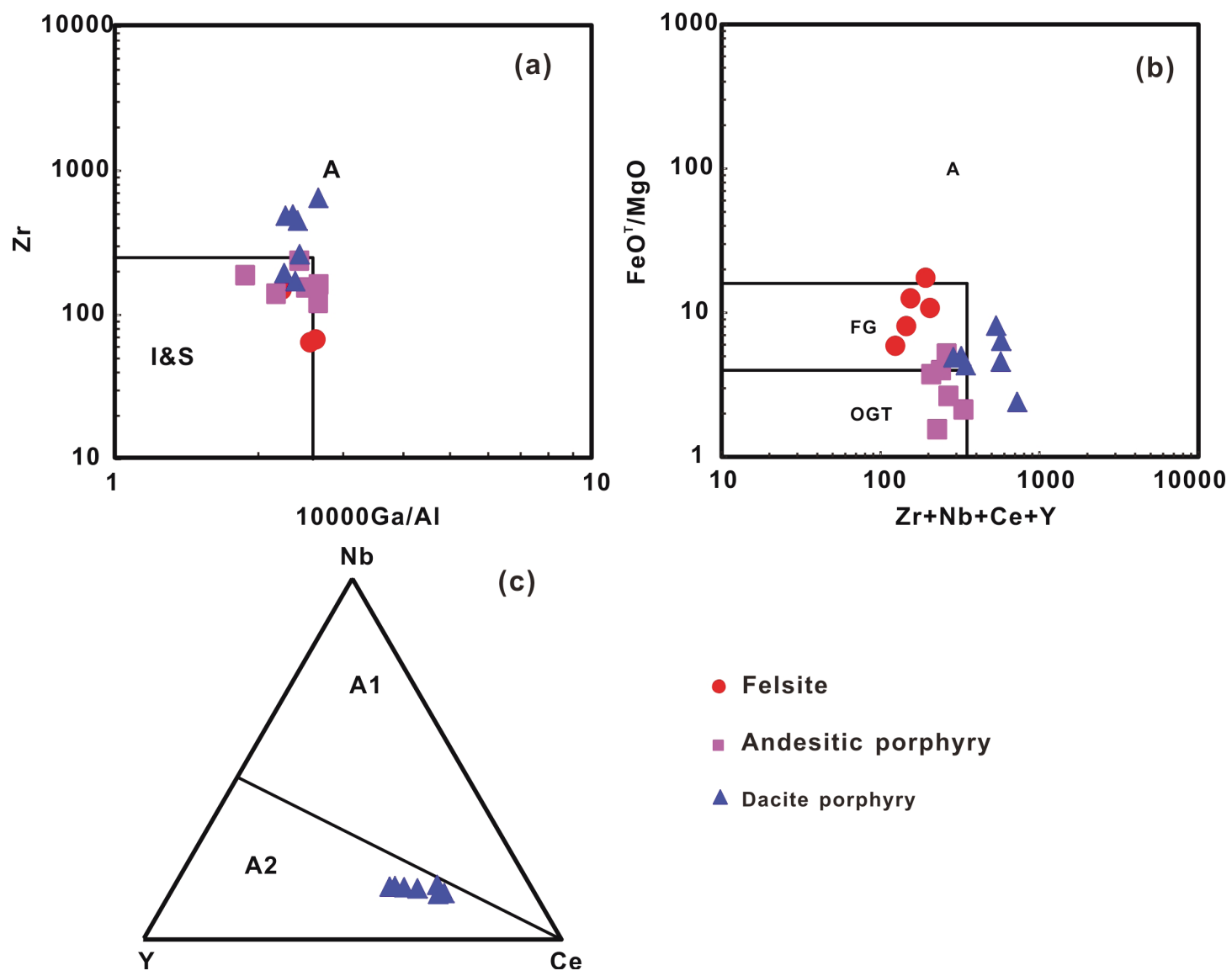

- Felsite

- Andesitic porphyry

$\Delta$ Dacite porphyry

Fig. 10. (a) Zr vs. 10000Ga/Al classification diagrams (Whalen et al., 1987); (b) FeO $\mathrm{O}^{\mathrm{T}} \mathrm{MgO}$ vs. $\mathrm{Zr}+\mathrm{Nb}+\mathrm{Ce}+\mathrm{Y}$ classification diagrams (Whalen et al., 1987); (c) The $A_{1}$ and $A_{2}$ subgroup discriminations of A-type granites (Eby, 1992); FG: Fractionated felsic granites; OGT: unfractionated $M$-, I- and S-type granites; $A_{I}$ suggest a post-orogenic tectonic setting; $A_{2}$ show an anorogenic environment.

Source and petrogenesis of the subvolcanic rocks

The majority of granites in northeast China were emplaced between the late Paleozoic and the late Mesozoic. These granites have low initial ${ }^{87} \mathrm{Sr} /{ }^{86} \mathrm{Sr}$ ratios $(0.705 \pm$ 0.001 ), positive $\varepsilon_{\mathrm{Nd}}(T)$ values ( +4 to 0 ), and fairly young $T_{\text {DM }}$ model ages (1300-500 Ma). Jurassic basalts within the Manketouebo Formation of the southern Great Xing'an Range have low initial ${ }^{87} \mathrm{Sr} /{ }^{86} \mathrm{Sr}$ ratios $(0.70489-$ $0.70499)$, low $\varepsilon_{\mathrm{Nd}}(T)$ values ( -0.1 to 0.7$)$, and young $T_{\mathrm{DM} 2}$ ages (830-770 Ma) (Fan et al., 2008). Liu et al. (2005) reported that Linxi granitoids (Ma'anzi, Yelaigai, and Longtoushan intrusions in Fig. 1b) have initial ${ }^{87} \mathrm{Sr} /{ }^{86} \mathrm{Sr}$ ratios of $0.701764-0.707654$ and $\varepsilon_{\mathrm{Nd}}(T)$ values of -2.89 to +5 .60. In addition, Huang et al. (1986) used geophysical data and mathematical modeling to suggest that the Linxi granitoids are linked at depth and form a single granitic stock under the Dajing deposit, with Liu et al. (2001) using geochemical data to suggest that the Linxi granitoids and subvolcanic rocks in this area have a common source. This indicates the existence of genetic relationships be- tween the Linxi granitoids and subvolcanic rocks within the Dajing deposit. In addition, the porphyritic dacite in the study area has a positive $\varepsilon_{\mathrm{Nd}}(T)$ value $(+3.45)$ and a young $T_{\mathrm{DM}}$ model age (562.8 Ma, e.g., Xiao et al., 2004), similar to the $\mathrm{Sr}-\mathrm{Nd}$ compositions of rocks in the surrounding area (e.g., Linxi granitoids). Previously published data suggest that the subvolcanic rocks in this area were derived from partial melting of depleted lithospheric mantle or depleted mantle that contained crustal material.

\section{Tectonic setting}

Late Paleozoic to Mesozoic intrusive rocks are widespread throughout northeast China. These magmatic events have been the focus of a significant amount of geological, petrological, and geochronological research, but the tectonic setting of these events remains controversial. Four main models have been proposed to explain these magmatic events: (1) magmatism associated with a mantle plume or other intraplate process (Ge et al., 2000; 

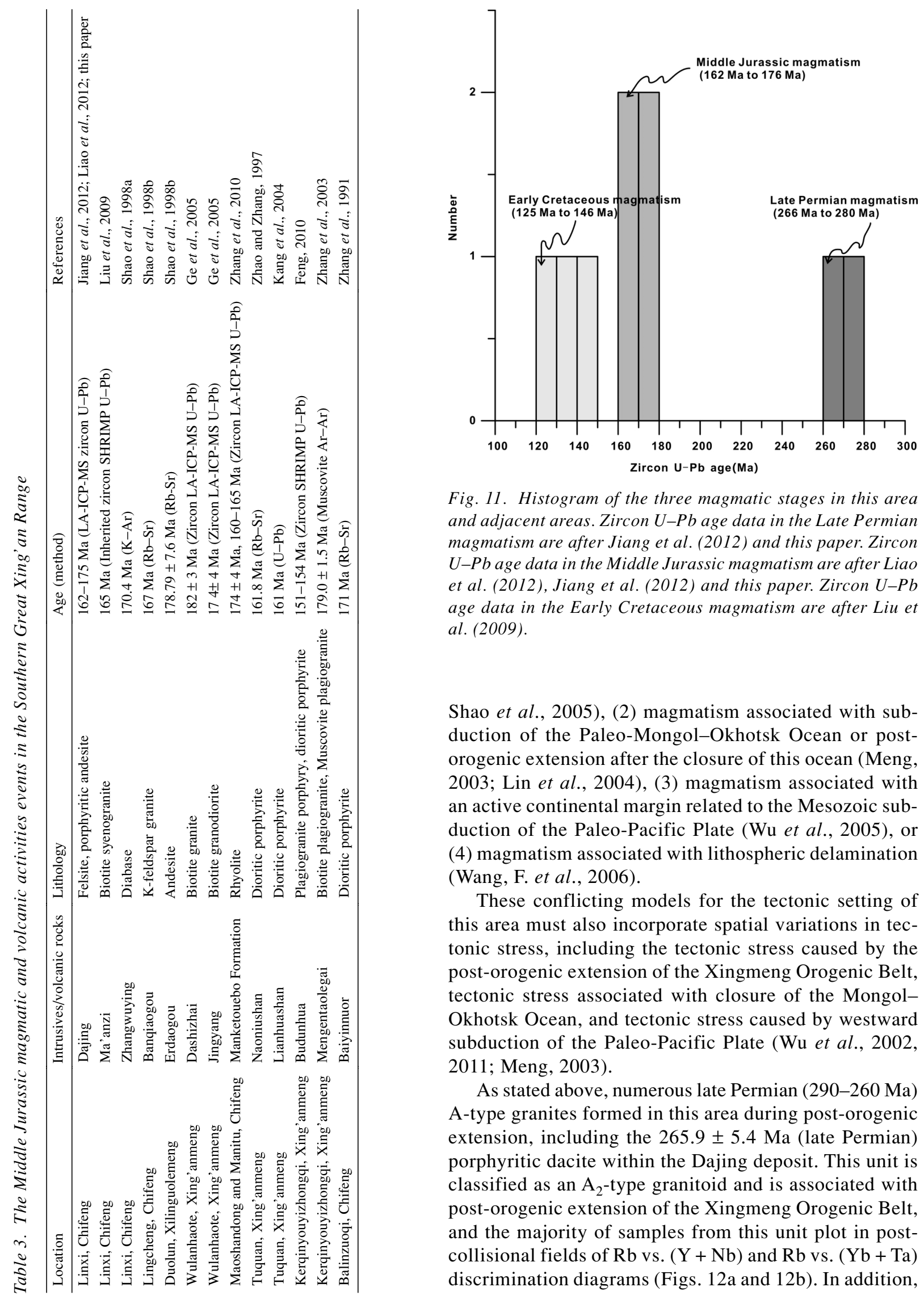

Fig. 11. Histogram of the three magmatic stages in this area and adjacent areas. Zircon $U-P b$ age data in the Late Permian magmatism are after Jiang et al. (2012) and this paper. Zircon $U-P b$ age data in the Middle Jurassic magmatism are after Liao et al. (2012), Jiang et al. (2012) and this paper. Zircon U-Pb age data in the Early Cretaceous magmatism are after Liu et al. (2009).

Shao et al., 2005), (2) magmatism associated with subduction of the Paleo-Mongol-Okhotsk Ocean or postorogenic extension after the closure of this ocean (Meng, 2003; Lin et al., 2004), (3) magmatism associated with an active continental margin related to the Mesozoic subduction of the Paleo-Pacific Plate (Wu et al., 2005), or (4) magmatism associated with lithospheric delamination (Wang, F. et al., 2006).

These conflicting models for the tectonic setting of this area must also incorporate spatial variations in tectonic stress, including the tectonic stress caused by the post-orogenic extension of the Xingmeng Orogenic Belt, tectonic stress associated with closure of the MongolOkhotsk Ocean, and tectonic stress caused by westward subduction of the Paleo-Pacific Plate (Wu et al., 2002, 2011; Meng, 2003).

As stated above, numerous late Permian (290-260 Ma) A-type granites formed in this area during post-orogenic extension, including the $265.9 \pm 5.4 \mathrm{Ma}$ (late Permian) porphyritic dacite within the Dajing deposit. This unit is classified as an $\mathrm{A}_{2}$-type granitoid and is associated with post-orogenic extension of the Xingmeng Orogenic Belt, and the majority of samples from this unit plot in postcollisional fields of $\mathrm{Rb}$ vs. $(\mathrm{Y}+\mathrm{Nb})$ and $\mathrm{Rb}$ vs. $(\mathrm{Yb}+\mathrm{Ta})$ discrimination diagrams (Figs. 12a and 12b). In addition, 

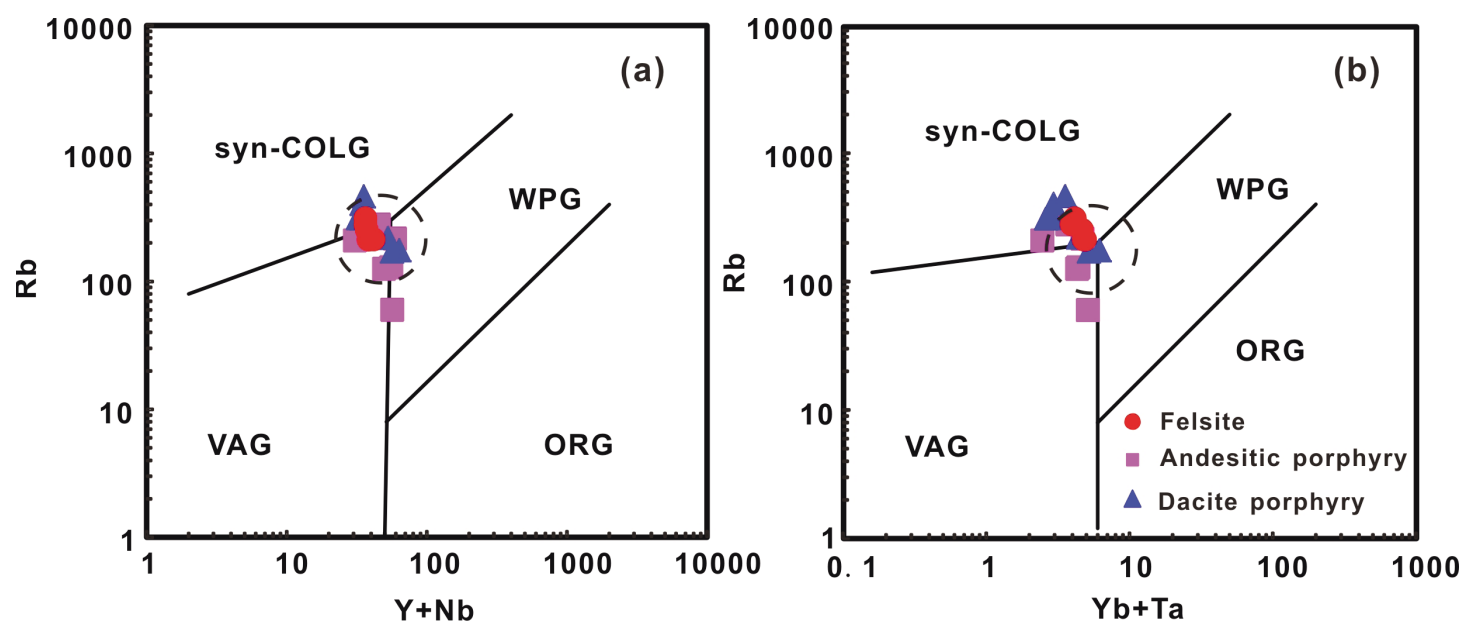

Fig. 12. (a) Rb vs. Y + Nb diagrams; (b) Rb vs. Yb + Ta diagram; (a) and (b) are from Pearce, 1996. VAG, Volcanic arc granite; $O R G$, ocean ridge granite; WPG, within-plate granite; Syn-COLG, Syn-collision granite.

Wu et al. (2002) suggested that the post-orogenic tectonic setting could be explained by a slab break-off model, suggesting that the magmatism that formed this porphyritic dacite was associated with post-collisional slab break-off.

The felsite and the porphyritic andesite in the Dajing deposit are I-type granitoids that were intruded at 168.4 \pm 5.0 and $175.5 \pm 5.6 \mathrm{Ma}$, respectively, both of which formed prior to the initiation of large-scale westward subduction of the Paleo-Pacific Ocean (140 Ma). This indicates that the westward subduction of the Paleo-Pacific Ocean had no effect on the study area. In addition, the Dajing deposit is located in the southern Great Xing'an Range, far from the Mongol-Okhotsk Ocean, indicating that this area was minimally affected by the closure of this ocean at $\sim 160 \mathrm{Ma}$. These findings indicate that both the felsite and the porphyritic andesite formed during the post-orogenic extension of the Xingmeng Orogenic Belt in an area that was influenced by far-field effects associated with the closure of the Mongol-Okhotsk Ocean. This inference is supported by the fact that the majority of samples from these intrusions plot in post-collisional fields of $\mathrm{Rb}$ vs. $(\mathrm{Y}+\mathrm{Nb})$ and $\mathrm{Rb}$ vs. $(\mathrm{Yb}+\mathrm{Ta})$ discrimination diagrams (Fig. 12a and 12b), suggesting that the postorogenic tectonic setting of this area was related to lithospheric delamination (Wu et al., 2002).

\section{CONCLUSIONS}

The geochronological and geochemical data presented here allow the following conclusions to be reached.

(1) Felsite, porphyritic andesite, and porphyritic dacite subvolcanic rocks are associated with the Dajing deposit. Zircon LA-ICP-MS U-Pb dating of these units indicates that the porphyritic dacite was intruded at $265.9 \pm 5.4$ Ma (late Permian) in a tectonic setting associated with post-collisional slab break-off. The felsite and the porphyritic andesite were intruded at $168.4 \pm 5.0$ and $175.5 \pm 5.6 \mathrm{Ma}$, respectively, and both most likely formed in a post-collisional extensional setting within the Xingmeng Orogenic Belt that was influenced by far-field effects of the closure of the Mongol-Okhotsk Ocean.

(2) The subvolcanic rocks associated with the Dajing deposit are high-K and calc-alkaline, and have high $\mathrm{A} /$ $\mathrm{CNK}$ ratios $(\mathrm{A} / \mathrm{CNK}>1)$. They are all preferentially enriched in LREE compared with HREE, and the felsite is characterized by relatively high concentrations of $\mathrm{Rb}, \mathrm{U}$, $\mathrm{Nd}, \mathrm{Zr}$, and $\mathrm{Hf}$, and relatively low concentrations of $\mathrm{Ba}$, $\mathrm{Sr}, \mathrm{P}$, and $\mathrm{Ti}$, similar to highly fractionated I-type granites. The porphyritic andesite contains relatively high concentrations of $\mathrm{Rb}$ and $\mathrm{K}$, and relatively low concentrations of $\mathrm{Ba}$, similar to unfractionated I-type granites. The porphyritic dacite is enriched in $\mathrm{Rb}, \mathrm{Zr}$, and $\mathrm{Hf}$, is depleted in $\mathrm{Ba}, \mathrm{Sr}, \mathrm{P}$, and $\mathrm{Ti}$, and is compositionally similar to $A_{2}$-type granites.

Acknowledgments-We would like to thank Chifeng Dajingzi Mining Co. Ltd. and Chifeng Zhongxing Mining Co. Ltd. for supporting our fieldwork. We are grateful to Tomoaki Morishita of Kanazawa University and Cosmas Kongnyuy Shang of the University of Tuebingen for reviewing our manuscript. This study was funded by the Yunkai orogenesis and $\mathrm{W}-\mathrm{Pb}-\mathrm{Zn}-\mathrm{Au}$ polymetallic mineralization (Grant No. CUG120702), and the Comprehensive Prospecting Prediction Research of Sandaoxi District in Linxi County, Inner Mongolia (2010020016).

\section{REFERENCES}

Eby, G. N. (1992) Chemical subdivision of the A-type 
granitoids: Petrogenetic and tectonic implications. Geology 20, 641-644.

Fan, W. M., Guo, F., Gao, X. F. and Li, C. W. (2008) Sr-Nd isotope mapping of Mesozoic igneous rocks in NE China: Constraints on tectonic framework and crustal growth. Geochimica 37(4), 361-372 (in Chinese with English abstract).

Feng, X. F. (2010) Studies on Geological-Geochemical Characteristics of the Budunhua Copper Deposit in Xinganmeng, Inner Mongolia. Chinese Academy of Geological Sciences, Beijing, 64 pp. (in Chinese with English abstract).

Ge, W. C., Lin, Q., Sun, D. Y., Wu, F. Y. and Li, X. H. (2000) Geochemical research into origins of two types of Mesozoic rhyolites in Daxinanling. Earth Science 25(2), 172-178 (in Chinese with English abstract).

Ge, W. C., Wu, F. Y., Zhou, C. Y. and Zhang, J. H. (2005) Zircon $\mathrm{U}-\mathrm{Pb}$ ages and its significance of the Mesozoic granites in the Wulanhaote region, central Da Hinggan Mountain. Acta Petrologica Sinica 21(3), 749-762 (in Chinese with English abstract).

Huang, S. Q., Lin, D. F., Yan, R. X. and Shi, Z. (1986) Geology and genesis of the Dajing $\mathrm{Sn}-\mathrm{Ag}-\mathrm{Cu}$ deposit. Geology and Prospecting 22, 28-32 (in Chinese with English abstract).

Irvine, T. N. and Baragar, W. R. A. (1971) A guide to the chemical classification of the common volcanic rocks. Can. J. Earth Sci. 8, 523-548.

Jiang, S. H., Liang, Q. L., Liu, Y. F. and Liu, Y. (2012) Zircon $\mathrm{U}-\mathrm{Pb}$ ages of the magmatic rocks occurring in and around the Dajing $\mathrm{Cu}-\mathrm{Ag}-\mathrm{Sn}$ polymetallic deposit of Inner Mongolia and constrains to the ore-forming age. Acta Petrologica Sinica 2, 495-513 (in Chinese with English abstract).

Kang, M., Cen, K., Luo, X. R. and Chen, X. (2004) Relationship between metallogenesis and magmatic activities in the Naoniushan-Julihe copper polymetallic ore belt. Eastern Inner Mongolia. Geoscience 18(2), 210-216 (in Chinese with English abstract).

LBGMR (Liaoning Bureau of Geology and Mineral Resources) (1976) Report on Geology and Exploration in the Dajing $\mathrm{Cu}$ Deposit. Inner Mongolia, 53 pp. (in Chinese).

Le Bas, M., Le Maitre, R. W. and Streckeisen, A. (1986) A chemical classification of volcanic rocks based on the total-silica diagram. J. Petrol. 27, 745-750.

Liao, Z., Wang, Y. W., Wang, J. B., Long, L. L., Zou, T., Zhang, H. Q. and Li, D. D. (2012) LA-ICP-MS zircon U-Pb dating of dykes of Dajing tin-polymetallic deposit, Inner Mongolia, China, and its geological significance. Acta Petrologica Sinica 7, 2292-2306 (in Chinese with English abstract).

Lin, Q., Ge, W. C., Wu, F. Y., Sun, D. Y. and Cao, L. (2004) Geochemistry of Mesozoic granites in Da Hinggan Ling ranges. Acta Petrologica Sinica 20, 403-412 (in Chinese with English abstract).

Liu, W., Li, X. J. and Tan, J. (2001) Petrogenetic and metallogenetic background of the Dajing $\mathrm{Cu}-\mathrm{Sn}-\mathrm{Ag}-\mathrm{Pb}-$ $\mathrm{Zn}$ ore deposit, Inner Mongolia, and characteristics of the mineralizing fluid. Resour. Geol. 51(4), 321-331.

Liu, W., Siebel, W., Li, X. J. and Pan, X. F. (2005) Petrogenesis of the Linxi granitoids, northern Inner Mongolia of China: Constraints on basaltic underplating. Chem. Geol. 219(14), 5-35.
Liu, W., Pan, X. F., Liu, D. Y. and Chen, Z. Y. (2009) Threestep continental-crust growth from subduction accretion and underplating, through intermediary differentiation, to granitoid production. Inter. J. Earth Sci. 98(6), 1413-1439.

Liu, Y. S., Hu, Z. C., Gao, S., Günther, D., Xu, J., Gao, C. and Chen, H. (2008) In situ analysis of major and trace elements of anhydrous minerals by LA-ICP-MS without applying an internal standard. Chem. Geol. 257, 34-43.

Liu, Y. S., Gao, S., Hu, Z. C., Gao, C. G., Zong, K. and Wang, D. B. (2010) Continental and oceanic crust recyclinginduced melt-peridotite interactions in the Trans-North China Orogen: $\mathrm{U}-\mathrm{Pb}$ dating, $\mathrm{Hf}$ isotopes and trace elements in zircons of mantle xenoliths. J. Petrol. 51, 537-571.

Ludwig, K. R. (2003) ISOPLOT 3.0: A Geochronological Toolkit for Microsoft Excel. Berkeley Geochronology Centre, Special Publication No. 4.

Mao, J. W., Xie, G. Q., Zhang, Z. H., Li, X. F., Wang, Y. T., Zhang, C. Q. and Li, Y. F. (2005) Mesozoic large-scale metallogenic pulses in North China and corresponding geodynamic settings. Acta Petrologica Sinica 21(1), 169188 (in Chinese with English abstract).

Meng, Q. R. (2003) What drove late Mesozoic extension of the northern China-Mongolia tract? Tectonophysics 369, 155174.

Middlemost, E. A. K. (1985) Magmas and Magmatic Rocks. Longman, London, $266 \mathrm{pp}$.

Pearce, J. A. (1996) Sources and settings of granitic rocks. Episodes 19, 120-125.

Peccerillo, R. and Taylor, S. R. (1976) Geochemistry of Eocene calc-alkaline volcanic rocks from the Kastamonu area, Northern Turkey. Contrib. Mineral. Petrol. 58, 63-81.

Shao, J. A., Gai, F. Y. and Zhang, L. Q. (1998a) Coupling of mantle-upwelling and shearing-Mesozoic dyke-swarms in Da-Hinggan mountains, Northeast China. Episode 21(2), 99-103.

Shao, J. A., Zhang, L. Q. and Mu, B. L. (1998b) Tectonothermal evolution of middle-south section of the Da Hinggan Mountains. Science in China (Series D) 41(6), 570-579.

Shao, J. A., Zhang, L. Q., Xiao, Q. H. and Li, X. B. (2005) Rising of Da Hinggan Mts in Mesozoic: A possible mechanism of intracontinental orogeny. Acta Petrologica Sinica 21, 789-794 (in Chinese with English abstract).

Sun, D. Y., Gou, J., Ren, Y. S., Fu, C. L., Wang, X. and Liu, X. M. (2011) Zircon U-Pb dating and study on geochemistry of volcanic rocks in Manitu Formation from southern Manchuria, Inner Mongolia. Acta Petrologica Sinica 27(10), 3083-3094 (in Chinese with English abstract).

Sun, S. S. and McDonough, W. F. (1989) Chemical and isotopic systematic of oceanic basalts: Implications for mantle composition and processes. Magmatism in the Ocean Basins (Saunders, A. D. and Norry, M. J., eds.), Geol. Soc. London Spec. Pub. 42, 313-345.

Wang, F., Zhou, X. H., Zhang, L. C., Ying, J. F., Zhang, Y. T., Wu, F. Y. and Zhu, R. X. (2006) Late Mesozoic volcanism in the Great Xing'an Range (NE China): timing and Implications for the dynamics setting of NE Asia. Earth Planet. Sci. Lett. 251, 179-198.

Wang, Y. W., Wang, J. B., Uemoto, T. and Wang, L. J. (2001) Geology and mineralization at the Dajing tin-polymetallic 
ore deposit, Inner Mongolia, China. Resour. Geol. 51(4), 307-320.

Wang, Y. W., Wang, J. B., Wang, L. J., Mao, Q. and Jiang, N. (2002) Study on the silver minerals of Dajing deposit, Inner Mongolia. Geol. Rev. 48(5), 526-533 (in Chinese).

Wang, Y. W., Wang, J. B., Wang, L. J. and Chen, Y. Z. (2006) Tin mineralization in the Dajing tin-polymetallic deposit, Inner Mongolia, China. J. Asian Earth Sci. 28(4-6), 320331.

Whalen, J. B., Currie, K. L. and Chappell, B. W. (1987) A-type granites: geochemical characteristics, discrimination and petrogenesis. Contrib. Mineral. Petrol. 95, 407-419.

Wiedenbeck, M., Allé, P., Corfu, F., Griffin, W. L., Meier, M., Oberli, F., Von Quadt, A., Roddick, J. C. and Spiegel, W. (1995) Three natural zircon standards for U-Th-Pb, LuHf, trace element and REE analyses. Geostand. Newsl. 19, $1-23$.

Wu, F. Y., Sun, D. Y., Li, H. M., Jahn, B. and Wilde, S. (2002) A-type granites in Northeastern China: Age and geochemical constraints on their petrogenesis. Chem. Geol. 187, 143173.

Wu, F. Y., Lin, J. Q., Wilde, S. A., Zhang, X. O. and Yang, J. H. (2005) Nature and significance of the Early Cretaceous giant igneous event in eastern China. Earth Planet. Sci. Lett. 233, 103-119.

Wu, F. Y., Sun, D. Y., Ge, W. C., Zhang, Y. B., Grant, M. L., Wilde, S. A. and Jahn, B. (2011) Geochronology of the Phanerozoic granitoids in northeastern China. J. Asian Earth Sci. 41(1), 1-30.

Wu, Y. B. and Zheng, Y. F. (2004) Study on the genesis of zircon and its restrictions on explaining the $\mathrm{U}-\mathrm{Pb}$ age. Chinese Sci. Bull. 49(16), 1589-1604 (in Chinese with English abstract).

Xiao, C. D., Zhang, Z. L. and Zhao, L. Q. (2004) Nd, Sr and Pb isotope geochemistry of Yanshanian granitoids in eastern Inner Mongolia and their origins. Chinese Geol. 31(1), 5763 (in Chinese with English abstract).

Zhang, D. Q. (1993) Two granitoid series in different tectonic environments of Southern Da Hinggan Mountains, China. Acta Petrologica et Mineralogica 12(1), 1-11 (in Chinese with English abstract).

Zhang, D. Q., Lei, Y. F., Luo, T. Y., Bao, X. P. and Wang, S. L. (1991) Geological characteristics and metallogeny of the Baiyinnuo Lead-Zinc deposit, Inner Mongolia. Mineral Deposits 10(3), 204-216 (in Chinese with English abstract).

Zhang, H. Q., Wang, J. B., Wang, Y. W., Wang, L. J., Long, L. L. and Liao, Z. (2011) The mineralization and prospecting significance of dykes of Dajing Tin-Polymetallic Deposit, Inner Mongolia. Geology and Exploration 3, 344-352 (in Chinese with English abstract).

Zhang, J. F., Pang, Q. B., Zhu, Q. and Jin, C. Z. (2003) Mengentaolegai $\mathrm{Ag}-\mathrm{Pb}-\mathrm{Zn}$ deposit in Inner Mongolia: ArAr age of muscovite and its significance. Mineral Deposits 22(3), 253-256 (in Chinese with English abstract).

Zhang, J., Gao, S., Ge, W., Wu, F., Yang, J., Wilde, S. and Li, M. (2010) Geochronology of the Mesozoic volcanic rocks in the Great Xing' an Range, northeastern China: Implications for subduction-induced delamination. Chem. Geol. 276(3-4), 144-165.

Zhao, Y. M. and Zhang, D. Q. (1997) Metallogeny and Prospective Evolution of Copper-Polymetallic Deposits in the Da Hinggan Mountains and Its Adjacent Regions. Seismological Press, Beijing, 318 pp. (in Chinese). 